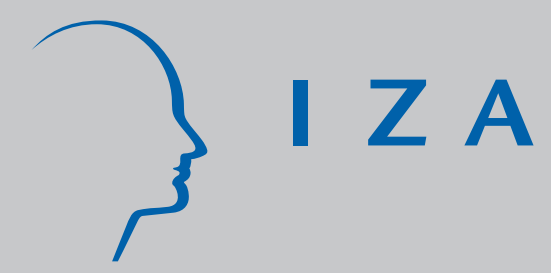

IZA DP No. 7731

Income vs. Consumption Inequality in South Korea:

Evaluating Stochastic Dominance Rankings by Various Household Attributes

Almas Heshmati

Robert Rudolf

November 2013 


\title{
Income vs. Consumption Inequality in South Korea: Evaluating Stochastic Dominance Rankings by Various Household Attributes
}

\author{
Almas Heshmati \\ Sogang University \\ and IZA \\ Robert Rudolf \\ Korea University \\ Discussion Paper No. 7731 \\ November 2013 \\ IZA \\ P.O. Box 7240 \\ 53072 Bonn \\ Germany \\ Phone: +49-228-3894-0 \\ Fax: +49-228-3894-180 \\ E-mail: iza@iza.org
}

\begin{abstract}
Any opinions expressed here are those of the author(s) and not those of IZA. Research published in this series may include views on policy, but the institute itself takes no institutional policy positions. The IZA research network is committed to the IZA Guiding Principles of Research Integrity.

The Institute for the Study of Labor (IZA) in Bonn is a local and virtual international research center and a place of communication between science, politics and business. IZA is an independent nonprofit organization supported by Deutsche Post Foundation. The center is associated with the University of Bonn and offers a stimulating research environment through its international network, workshops and conferences, data service, project support, research visits and doctoral program. IZA engages in (i) original and internationally competitive research in all fields of labor economics, (ii) development of policy concepts, and (iii) dissemination of research results and concepts to the interested public.
\end{abstract}

IZA Discussion Papers often represent preliminary work and are circulated to encourage discussion. Citation of such a paper should account for its provisional character. A revised version may be available directly from the author. 
IZA Discussion Paper No. 7731

November 2013

\title{
ABSTRACT \\ Income vs. Consumption Inequality in South Korea: Evaluating Stochastic Dominance Rankings by Various Household Attributes
}

\begin{abstract}
Using four rounds $(1999,2002,2005,2008)$ of the Korean Labor and Income Panel Study (KLIPS), this article examines determinants of household income and consumption levels and inequalities. Unconditional as well as conditional stochastic dominance (SD) tests are performed by year, by household heads' characteristics (age, education, gender, health, marital status and occupation) and by household characteristics (household type, household size, degree of urbanization). Mean least squares regression techniques are employed to predict conditional expectations. The residuals containing effects for each characteristic conditional on the remaining characteristics are then used for the SD analysis employing extended Kolmogorov-Smirnov tests of first- and second-order dominance in distribution of income and consumption. The results provide a detailed and up-to-date picture of inequality and poverty by subgroup in South Korea which helps targeting particularly vulnerable groups. Overall, while inequality in disposable income is found to be often substantial, strong savings preferences of richer households lead to relatively low consumption inequality. Households headed by elderly, uneducated, divorced or widowed, females and those with health problems are found to be the most vulnerable groups in Korea.
\end{abstract}

JEL Classification: D63, D31, I31, C14

Keywords: stochastic dominance, bootstrap, disposable income, consumption inequality, poverty, South Korea

Corresponding author:

Robert Rudolf

Division of International Studies

Korea University,

145, Anam-ro, Seongbuk-gu

Seoul 136-701

South Korea

E-mail: rrudolf@korea.ac.kr 


\section{Introduction}

Income inequality has been regarded a minor issue in the past in many East Asian nations. Due to the equalizing effects of large-scale land redistributions around the 1950s in many countries in the region, the political credo during the economic boom was "growth first, distribution later” (e.g. Adelman and Robinson, 1978; Fields and Yoo, 2000). This didn’t provoke too large countermovement given relative equality of chances within Asian populations. Equality of chances in turn is found to have stimulated human capital investment, in one part due to higher returns that farmers were able to earn on their 'own' plots, in other part due to the high competition for the best jobs in a society with relatively high social mobility. However, as growth rates are slowing down and increased international division of labor in combination with skill-biased technological progress have led to a widening of the wage-gap between high- and low-skilled workers, increasing inequality has become a major concern for almost all East Asian governments at the start of the $21^{\text {st }}$ century (Cain et al., 2011; Cheong, 2001; Villaverde and Maza, 2012; Xue and Zhong, 2003). Moreover, rapid population aging can be expected to further increase income dispersion as inequality within older age-cohorts is generally found to be higher than among younger cohorts (Deaton and Paxson, 1994; 1997; Rudolf and Kang, 2013; Zhong, 2011). Inequality within the elderly population is a particularly urgent matter for the Republic of Korea (South Korea), which features the highest relative poverty headcount among the retirement age population within the OECD. In 2011, after taxes and transfers, 48.6 percent of all elderly had disposable incomes below the poverty line. ${ }^{1}$ All this has led governments to embrace the concept of a welfare state and the design of such welfare systems dominates public debates and election campaigns.

Income and consumption inequality exert various effects on a country's well-being. First, it is found that income inequality can retard economic growth (Deininger and Squire, 1998; Barro, 2000; Banerjee and Duflo, 2003; Castello-Climent, 2010; Herzer \& Vollmer, 2012). Inequality is also found to increase political instability, which in turn tends to reduce investment and production volumes (Alesina and Perotti, 1996). In addition, a

\footnotetext{
${ }^{1}$ The poverty line is a relative poverty line defined as $50 \%$ of the median equalized household disposable income (OECD, 2013).
} 
negative, two-way relationship is found between income inequality and institutional quality (Chong and Gradstein, 2007).

Not only does income inequality affect macroeconomic outcomes, but it also affects individual well-being in a direct way. Given a certain level of average income, higher inequality means higher poverty which leads to deprivation and social exclusion with both short and long-run implications for individual and social well-being.

Latest studies using subjective well-being measures additionally show that a person's relative income position is a strong predictor of life satisfaction, happiness, and psychological well-being in general (Diener et al., 1993; Cummins, 2000; McBride, 2001; Clark et al., 2008; Kahneman \& Deaton, 2010). Relative income deprivation is moreover found to be associated with lower self-rated health condition (Subramanyam et al., 2009).

As predicted by economic theory, households will tend to smooth consumption over time if purchasing power can be stored effectively, i.e. if they have access to efficient financial markets. In addition, high-income households and low-income households differ in their marginal propensity to consume, equalizing consumption but increasing wealth inequality in the long run. Thus, while consumption inequality is usually observed to track income inequality, it is found to be of a smaller degree (Krueger and Perri, 2006; Domeij and Floden, 2010; Heathcote et al., 2010; Japelli and Pistaferri, 2010; 2011; Aguiar and Bils, 2011; Rudolf and Kang, 2013).

This paper examines the existence of uniform weak orders between Korean welfare outcomes measured by household per-capita disposable income and consumption expenditure. Stochastic dominance (SD) analysis is used in order to reveal "more complete” distributional information as compared to index-based 'average' inequality measures such as the Gini, Theil, or Generalized Entropy. SD analyses thus provide suitable test statistics for ranking distributions. It allows us to compare distributions in greater detail and draw conclusions based on levels of confidence and statistical significance. This renders SD results a better instrument for ranking and policy analysis, particularly in identifying and tracking target groups (McFadden, 1989; Barret and Donald, 2003; Linton et al., 2005; Maasoumi and Heshmati, 2000; 2008). Unconditional as well as conditional stochastic dominance (SD) tests are performed by year, by household heads' 
characteristics (age, education, gender, health, marital status and occupation) and by household characteristics (household type, household size, degree of urbanization). Mean least squares regression techniques are employed to predict conditional expectations. The residuals containing effects for each household (heads) characteristic conditional on the remaining characteristics are then used for the SD analysis employing extended Kolmogorov-Smirnov tests of first- and second-order dominance in distribution of disposable income and consumption expenditure. The results provide a detailed and up-todate picture of inequality and poverty in Korea which helps targeting particularly vulnerable groups like the elderly and low-skilled workforce. It further contributes to the literature in that the relationship between income and consumption is examined in detail using SD orderings by household attributes. Earlier work applying similar approaches to Sweden and the U.S. has mainly focused on the relationship between gross and disposable income (Maasoumi and Heshmati, 2000; 2008). Overall, while inequality in disposable income is found to be often substantial, strong savings preferences of richer households lead to relatively low consumption inequality.

The remainder of the paper is organized as follows. Section II presents the methodology of first and second order stochastic dominance and the test statistics derived from it. In Section III, the data set is introduced and results from testing distributions of income and consumption for SD rankings are discussed. Conclusions and policy recommendations are drawn in Section IV.

\section{Methodology}

In this study we examine the existence of uniform weak orders between welfare outcomes measured by real incomes and consumption expenditures. Partial strong orders are commonly used on the basis of specific utility functions and their corresponding indices. The indices are in practice the predominant form of evaluation. However, such strong orderings do not command consensus, neither among scholars nor among policy makers. Based on the expected utility paradigm, Stochastic Dominance, Lorenz and Generalized Lorenz are examples of 'orderings' that attempt to resolve this disagreement 
problem. It is well-known that, in evaluating distributed outcomes, average outcomes mask the differential impact on different program participants and render index-based assessments as blunt instruments for policy analysis. In contrast, SD analyses have the advantage that they reveal all of the distributional changes, especially amongst the compared target groups.

We largely follow the methodology of Maasoumi and Heshmati (2000; 2008) used for analyzing Swedish and U.S. income distributions. In contrast to those studies, which focused on the relationship of gross vs. disposable incomes, here using Korean household panel data we focus on disposable income vs. consumption expenditure. Thus, by including consumption expenditure into the analysis we move one step closer towards evaluating households' actual welfare.

\section{First and Second Order Stochastic Dominance}

Let $X_{1}$ and $X_{2}$ be two variables related to household income or consumption expenditure at either two different points in time or from two different strata (e.g. married vs. single). Let $X_{k i}(\mathrm{i}=1, \ldots, \mathrm{N} ; \mathrm{k}=1,2)$ denote the not necessarily i.i.d. observations. Let $U_{1}$ denote the class of all von Neumann-Morgenstern type utility functions $u$, such that $u$ ' $\geq$ 0 (increasing). Also, let $U_{2}$ denote the class of all utility functions in $U_{1}$ for which $u$ " $\leq 0$ (strict concavity), and $U_{3}$ denote a subset of $U_{2}$ for which $u^{\prime \prime} \geq 0$. Let $X_{(1 p)}$ and $X_{(2 p)}$ denote the $p$-th quantiles, and $F_{1}(x)$ and $F_{2}(x)$ denote the cumulative distribution functions, respectively.

Definition 1. $X_{1}$ First Order Stochastic Dominates $X_{2}$, denoted $X_{1} \operatorname{FSD} X_{2}$, if any of the following equivalent conditions holds:

$E\left[\left(u\left(X_{1}\right)\right] \geq E\left[u\left(X_{2}\right)\right]\right.$ for all $u \in U_{1}$, with strict inequality for some u, or (1)

$F_{1}(x) \leq F_{2}(x)$ for all $\mathrm{x}$ with strict inequality for some $\mathrm{x}$; or

$X_{(1 p)} \geq X_{(2 p)}$ for all $0 \leq \mathrm{p} \leq 1$, with strict inequality for some $\mathrm{p}$. 
Definition 2. $X_{1}$ Second Order Stochastic Dominates $X_{2}$, denoted $X_{1} \operatorname{FSD} X_{2}$, if any of the following equivalent conditions holds:

$$
\begin{aligned}
& E\left[u\left(X_{1}\right)\right] \geq E\left[u\left(X_{2}\right)\right] \text { for all } u \in U_{2} \text {, with strict inequality for some u; or } \\
& \int_{-\infty}^{x} F_{1}(t) d t \leq \int_{-\infty}^{x} F_{2}(t) d t \text { for all x with strict inequality for some } \mathrm{x} \text {; or } \\
& \Phi_{1}(p)=\int_{0}^{p} X_{(1 t)} d t \geq \Phi_{2}(p)=\int_{0}^{p} X_{(2 t)} d t \text { for all } 0 \leq \mathrm{p} \leq 1 \text {, with strict } \\
& \text { inequality for some value(s) } p .
\end{aligned}
$$

\section{Test Statistics}

The tests of first and second orders of dominance are based on empirical evaluation of the conditions (2) and (3) and (5) and (6) in the above definitions. Conducting tests on conditions (3) and (6) relies on the quantiles to be consistently estimated by the corresponding order statistics at a finite number of sample points and tests on conditions (2) and (5) requires empirical $c d f s$ and comparison at a finite number of observed ordinates. It should be noted that first order stochastic dominance implies second order stochastic dominance.

We follow an alternative bootstrap procedure for estimating the probability of rejection of the SD hypotheses with a suitably extended Kolmogorov-Smirnov (KS) test for first and second order stochastic dominance. Alternative simulation and bootstrap implementations of this test have been examined by McFadden (1989), Klecan, McFadden and McFadden (1991), and Barrett and Donald (2003). Linton et al. (2005) in a general approach allow for very general sampling schemes based on subsampling. We employ matched pairs over time to preserve dependence between variables that are ranked, but looking at the observed waves of the KLIPS data, separated by several years, likely removes the dependence problem in the cases we consider here. In similarity with Linton et al. (2005), our approach does not impose the boundary of the null of dominance and avoid null hypothesis bias on the boundary. 
Suppose that there are two prospects $X_{1}, X_{2}$ and let $A=\left\{X_{k}: k=1,2\right\}$. Let $\left\{X_{k i}: i=\right.$ $1,2, \ldots, N\}$ be realizations of $X_{k}$ for $k=1,2$. These values could be 'residuals' of income or expenditures 'purged' of the influence of certain desired attributes, such as age, education, marital status, and gender. When data are limited, one may want to use a model to control for such attributes. Here first we follow an alternative strategy of grouping the data into subsets, say of families with different sizes, or by educational attainment of the head, and then make comparisons across homogeneous populations. For $k=1$, 2 define:

$$
F_{k}(x, \theta)=P\left(X_{k i}(\theta) \leq x\right)
$$

and

$$
\bar{F}_{k N}(x, \theta)=\frac{1}{N} \sum_{i=1}^{N} 1\left(X_{k i}(0) \leq x\right)
$$

We denote $F_{k}(x)=F_{k}\left(x, \theta_{k 0}\right)$ and $\bar{F}_{k N}(x)=\bar{F}_{k N}\left(x, \theta_{k 0}\right)$, and let $F\left(x_{1}, x_{2}\right)$ be the joint c.d.f. of $\left(X_{1} X_{2}\right)^{\prime}$. Now define the following functional of the joint distribution:

$$
\begin{aligned}
& d=\min _{k \neq l} \sup _{x \in \chi}\left[F_{k}(x)-F_{l}(x)\right] \\
& s=\min _{k \neq l} \sup _{x \in \chi} \int_{-\infty}^{x}\left[F_{k}(t)-F_{l}(t)\right] d t
\end{aligned}
$$

Where $\chi$ denotes a given set contained in the common support of $X_{1 i}$ and $X_{2 i}$. Without loss of generality we assume that the supports are bounded. The hypotheses of interest are:

$$
\begin{aligned}
& H_{0}^{d}: d \leq 0 \quad \text { vs. } H_{1}^{d}: d>0 \\
& H_{0}^{s}: s \leq 0 \quad \text { vs. } H_{1}^{s}: s>0
\end{aligned}
$$

The null hypothesis $H_{0}^{d}$ implies that the prospects in $A$ are not first-degree stochastically maximal, i.e., there exists at least one prospect in $A$ which first-degree stochastically dominates the other. Likewise interpretation is done for the second order case.

The test statistics we consider are based on the empirical analogues of (9)-(10). They are defined to be: 


$$
\begin{aligned}
& D_{N}=\min _{k \neq l} \sup _{x \in \chi} \sqrt{N}\left[\bar{F}_{k N}\left(x, \dot{\theta}_{k}\right)-\bar{F}_{l N}\left(x, \dot{\theta}_{l}\right)\right] \\
& S_{N}=\min _{k \neq l} \sup _{x \in \chi} \sqrt{N} \int_{-\infty}^{x}\left[\bar{F}_{k N}\left(t, \dot{\theta}_{k}\right)-\bar{F}_{l N}\left(t, \dot{\theta}_{l}\right)\right] d t
\end{aligned}
$$

Weak orders of SD are obtained by eliminating the requirement of strict inequality at some point. When these conditions are not met, as when Generalized Lorenz Curves of two distributions cross, unambiguous first and second order SD relation is not possible. In such case, any strong ordering by specific indices corresponding to the utility functions $U 1$ and U2 classes will generally not enjoy consensus. In this relation, Whitmore (see Whitmore and Findley; 1978) introduced the concept of third order stochastic dominance (TSD) corresponding to 'transfer sensitivity’ requirement (see Shorrocks and Foster, 1987) in ranking of income distributions. Since the asymptotic null distribution of these tests depends on the unknown distributions, McFadden (1989) and Klecan, McFadden and McFadden (1991) proposed a Monte Carlo permutation procedure for the computation of critical values. On the other hand Linton et al. (2005) test is based on a subsampling procedure which approximates the true sampling distribution under the composite null hypothesis. This test might be asymptotically more powerful than the bootstrap-based or simulation-based tests for some local alternatives. The approach used in current case fixes the critical value (zero) at the boundary of our null, and estimates the associated 'significance level' by bootstrapping the sample or its blocks. This renders our tests 'asymptotically similar' and unbiased on the boundary. This is similar in spirit to inference based on p-values. This method could also be used to compare the two distributions up to any desired quantile, for instance, for poverty rankings.

\section{Testing for SD in KLIPS data}

\section{Data}

Data for the analysis comes from the Korean Labor and Income Panel Study (KLIPS) for the years 1999, 2002, 2005, and 2008. KLIPS is a nationally representative longitudinal survey of urban Korean households, modeled after the National Longitudinal Surveys 
(NLS) and the Panel Study of Income Dynamics (PSID) of the U.S. It is conducted annually by the Korea Labor Institute, a government-sponsored research institute. The study started in 1998 with 5,000 households and 13,783 individuals aged 15 years or older. KLIPS collects a wide range of information on individuals, such as earnings, education, family and employment backgrounds, and demographic characteristics. The data quality KLIPS provides satisfies international standards. KLIPS maintains 76 percent of the original sample after 10 years. ${ }^{2}$ The maintained level of KLIPS is similar to those of the US PSID (78 percent); the German Socio-economic Panel (GSOEP, 79 percent); and the British Household Panel Survey (BHPS, 77 percent). ${ }^{3}$

As our main focus lies on ranking the distributions of households' disposable income and consumption expenditure, our main variables are "average monthly disposable percapita household income” and “average monthly per-capita household living expenses”, respectively. Disposable income includes labor earnings, incomes from savings and investment, and is net of taxes as well as public and private transfers. Living expenses include expenditure on food, housing, clothing, education, health and medical fees, transportation, communication, and other utilities. Living expenses do not include repayment of debt or scheduled payments for savings. Irregular, one-time expenses arising from special occasions (marriage, accidents, etc.) are also not included. We decided to use per-capita values instead of using a lower weight for children, given the very high private cost of education and child-raising in Korea. All prices were transformed into real values using provincial consumer price indices (CPIs) with base year 2005. A household is identified by its household head which is usually the self-reported head. However, if a spouse is present, then the individual among the two with the higher earnings is defined as the head.

In the following analysis we exploit the dynamic nature of our panel data set. In total, we observe 2,993 households which are present over all four waves. Using this subsample as a balanced panel will first allow us to evaluate improvements in monetary well-being over time. Second, when comparing distributions by household attributes, we will use

\footnotetext{
${ }^{2}$ The retention rate was 88 percent in the second year (1999), 77 percent in the fifth year (2002), and 76 percent in 2007.

${ }^{3}$ Kang (2010) shows that potential biases produced by sample attrition are negligible in KLIPS.
} 
time-averaged household incomes and expenditures and relate those to household attributes from the last wave in 2008. Using the last wave of household's attributes enables us to draw more up-to-date policy recommendations from the analysis. The use of timeaverages of income and consumption allows for stability in the comparisons by removing year-to-year fluctuations and instead focusing on between-household differences. This procedure provides measures of permanent income and expenditure purged of transitory shocks. Korean households can be expected to be able to smooth transitory shocks relatively easily with the help of financial markets as well as public and private transfers. In line with the permanent income hypothesis, relative poverty and inequality in an environment with partial insurance will be determined primarily by a person's permanent income which depends on the sum of discounted expected life time earnings (Friedman, 1957; Deaton, 1997).

Table 1 presents summary statistics of the household per-capita income and consumption expenditures over time and by household attribute. ${ }^{4}$ Real monthly per-capita disposable income increased from \#528,600 (approx. US\$ 516) ${ }^{5}$ just after the Asian Financial Crisis in 1999 to 846,600 (approx. US\$ 827) in 2008, just before the start of the Global Financial Crisis. While the dispersion of disposable incomes went up initially (coefficient of variation (CV) increased from 1.04 (1999) to 1.25 (2002)), it reduced by the end of the 2000s (CV=0.98). Regarding household consumption, real monthly per-capita living expenses went up from $\$ 357,900$ (US\$ 350) in 1999 to 543,500 (US\$ 531) in 2008. Thus, while average real disposable incomes grew by 60 percent over this 9 year period, average consumption grew by 52 percent. In terms of consumption expenditures, there is also a slight downward trend in dispersion according to the CV. Note that, as predicted by the Life-Cycle-Permanent-Income Hypothesis (LCPIH), dispersion in consumption is much less than in incomes, pointing towards consumption smoothing behavior of households. In addition, overall savings seem to have increased over time:

\footnotetext{
${ }^{4}$ About 1 percent of all observations had missing data on incomes and 0.7 percent on expenditures. These were imputed using the lag or average value of the same household in other years. When all entries were missing for a particular household, predicted values from a regression-based approach were used.

${ }^{5}$ The value is converted into US dollar by using the average exchange rate for 2005 , which was 1,024 \#/\$US.
} 
While households in 1999 saved on average about 32 percent of their disposable incomes, in 2008 average savings stood at 36 percent.

The second part of Table 1 presents summary statistics of time-averaged incomes and expenditures by household attribute in 2008. Per-capita disposable income is highest in households with 3 or 4 members, which coincides with Korea's most frequent household arrangement. The highest inequality among all 5 household size groups is found within one-person households. Per-capita consumption does not differ much by household size. When regarding household type, married couples with children show highest per-capita income and expenditures. Lowest values are found for singles living with elderly. This is in line with the phenomenon of extraordinarily high old-age poverty, which is one of the major policy challenges in Korea (Hong and Kim, 2012). Next, we classify households by province of residence. As expected, more urbanized regions allow for both higher incomes and higher consumption.

The bottom panel of Table 1 examines differences by characteristics of the household head. Mean income and consumption are highest for households with heads between 30 and 65 years of age. ${ }^{6}$ The phenomenon of older age cohorts having higher within-cohort inequality is a widely acknowledged fact (see e.g. Deaton, 1997; Rudolf and Kang, 2013) and can be clearly observed in the Korean data. While among households with heads of 30 years and below the coefficient of variation is only 0.5 for disposable income, it is more than double as high for households with heads in retirement age. Thus, society aging 'naturally' puts an upward pressure on income and (to a lesser extent) consumption inequality.

About one fourth of all households are female-headed. Compared to these, maleheaded households have per-capita disposable incomes (consumption expenditures) which are about 30 percent (15 percent) higher. As acknowledged in the literature (e.g. Rudolf and Kang, 2014; OECD, 2011; UNDP, 2005; WEF, 2010), there is still a significant gender gap present in the Korean society.

The returns to education are also substantial in Korea and are found to range around 8 percent for disposable income and 4 percent for consumption per additional year of

\footnotetext{
${ }^{6}$ Note that, as stated above, this is the average income from 1999 to 2008, but the age measured in 2008 .
} 
schooling of the household head. If the head holds a tertiary degree, disposable income (consumption expenditure) goes up by on average 32 (26) percent compared to a household with high-school-only degree head and by 230 (108) percent compared to a household head with no schooling. The latter are the most vulnerable, as average consumption expenditures just match disposable income. Thus, even regular living expenses for these on average poor households are highly budget-constrained, even after transfers received from both government and relatives. Interestingly, as income dispersion is substantially higher within the less educated groups, no such effect can be found for consumption, again pointing towards consumption smoothing particularly among the poorer households.

Regarding marital status, if the head is married or has never married, income and consumption is substantially higher than in households with a separated, divorced, or widowed head. Thus, the latter households can be regarded to be among the most vulnerable.

The health status of the household head is another important correlate with income and consumption. Households whose heads report their health as being "excellent" or "good" have disposable incomes about 90 percent higher than those with heads reporting "poor” or “very poor” health status.

\section{Ranking distributions of income and consumption}

The following results are based on 1,000 bootstrap samples and partitions of the total income/expenditure range into twenty equally-sized bins. In comparing two distributions, the first is referred to as the " $X$ " distribution, and the second as the " $Y$ " distribution. Thus, "FSDxoy" denotes "first order stochastic dominance of $X$ over $Y$ ", and "SSDxoy" analogously denotes "second order dominance of $X$ over $Y$ ". The joint tests of $X v s$. $Y$ and $Y$ vs. $X$, referred to as "maximality" by McFadden (1989), are denoted "FOmax" and "SOmax". 


\section{a) Comparison by year of observation}

Table 2 presents the results of ranking the distributions of disposable income and consumption expenditure by year of observation. Two forms of results were estimated: First, displayed in the left panel of Table 2 are the results of comparing unconditional distributions where household attributes are not controlled for. That is, we raise the question of how income distributions from different years compare without taking into account changes in the demographic and socio-economic structure of the household. Second, displayed in the right panel of Table 2 are the conditional results from using the distribution of residuals of the regression of income and expenditure on all other attributes except the one the ranking is based on (here: year of observation). The conditional distribution analysis has the advantage that it isolates the effects of certain characteristics making comparison between segments of an attribute more exact.

The results show several cases of second order dominance. When looking at unconditional results only, we find significance of SSDyox (second-order stochastic dominance of $Y$ over $X$ ) in all cases. For both distributions of disposable income and consumption expenditure this indicates that more recent years dominate earlier years. Unconditional distributions are further displayed in Figures 1 and 2, which show empirical $c d f$ s for disposable income and consumption expenditure by year. Substantial improvements can be observed over time.

When conditional results are concerned, it becomes clear that the sources of these improvements lie inside of households. Changes in demographic and socio-economic household characteristics do account for the major part of the advancement. The right panel of Table 2 shows that 'pure' year or productivity improvements only remain in five out of twelve cases. All later years show an improvement over 1999 in terms of income, which is not surprising as recovery from the Asian Financial Crisis was still incomplete in 1999. In addition, disposable incomes in 2008 dominate those in 2005. Interestingly, dominance switches now for the years 2002 and 2005, with the latter being dominated by the former. In terms of consumption expenditure, the year 2002 dominates both 1999 and 2005. This might be interpreted as a kind of bouncing back from the crisis during which certain consumption (such as durable consumer goods) might have been postponed. 


\section{b) Comparison by household size}

Table 3 shows dominance rankings by household size. Results reveal interesting differences between income and expenditure and with respect to conditional vs. unconditional rankings. First, regarding unconditional disposable incomes, households with three or four members show frequent second-order stochastic dominance (SSD) over all other households. Consumption, however, is much more equally distributed across household sizes. Here we find only one case of SSD. Second, conditioning on household attributes turns the results upside down. Now, for both income and expenditure, and in 19 out of 20 cases, smaller households second-order stochastically dominate (SSD) larger households with one-person households ranking first. The difference between conditional and unconditional results is likely to be due to an over-representation of widowed and divorced elderly females in one-person households, and not to the nature of one-person households itself.

\section{c) Comparison by age of household head}

Table 4 presents the results of ranking distributions by age of household head. Regarding unconditional disposable incomes, households with heads of age 65 and above are dominated (SSD) by all other age groups. The second 'poorest' age cohort is that up to the age of 30. Households with ages 31 to 64 are not dominated in any comparison whatsoever. In terms of consumption, we find much less dominance. Heads in retirement age are second-order dominated by those aged 41 to 50 and 51 to 65 . Unconditional empirical $c d f s$ are illustrated also in Figures 3 and 4 . It is evident that the elderly are clearly dominated by all other age groups.

When looking at conditional results, the only dominated (SSD) group is the group of households with elderly heads. This confirms the urgency of the issue of old-age poverty in one of the fastest aging societies worldwide. 


\section{d) Comparison by education of household head}

In Table 5, we rank income and expenditure distributions by education of household head. As expected, higher years of schooling always SSD lower years of education in terms of unconditional disposable income. This is less so, however, when it comes to consumption. Here, only households with heads that have no schooling are dominated. Apparently, there is no statistically significant difference between all other education cohorts. Less stochastic dominance is found in the conditional results. As these control for a number of important determinants of income, this is less surprising.

\section{e) Comparison by household type}

Table 6 shows the analysis by household type. Married couples with children SSD all other types and thus are the 'richest' type of household in terms of per-capita disposable income. It is noteworthy that married couples with children SSD married couples without children. Given strongly male-dominated labor markets, high cost of raising children, and a shortage of women in the age cohorts relevant for marriage in Korea, we can expect that men with prospects of high future earnings have a higher probability of marriage and having children (Rudolf and Kang, 2014). Single households are found to be the 'poorest'. Note that here, similar to table 3, conditional results which control, among other factors, for education change the picture and put single households into a better position.

\section{f) Comparison by marital status of household head}

Table 7 reveals income and expenditure rankings with regard to marital status of the household head. Unconditional findings see households with "never married" or "married" heads second-order dominating those with "separated, divorced, or widowed" heads in terms of disposable income. In addition to this, conditional results show that "married" SSD "never married". The rankings are basically confirmed for the consumption case, however, not significant in all cases here. 


\section{g) Comparison by sex of household head}

As we expected from the descriptive statistics in Table 1, results in Table 8 confirm that male-headed households in Korea do still show significantly higher per-capita income and consumption levels than their female-headed counterparts. Male-headed households SSD female-headed households in three out of four cases with the only exception being the conditional results on consumption expenditure. This is in line with earlier studies showing that Korea, while having made rapid advances in catching up with high-income economies, significantly lacks behind in empowering women (e.g. Rudolf and Kang, 2014).

\section{h) Comparison by occupation of household head}

Table 9 presents the rankings according to the occupation of the household head. "Professionals”, being the highest-skilled group, SSD “service sector" and "agriculture and handicraft", while "service sector" further dominates "agriculture and handicraft" in terms of unconditional income and consumption rankings. When turning to the conditional case however, the differences are insignificant, as now education differences are already controlled for.

\section{i) Comparison by province of residence}

That the degree of urbanization is strongly related with income and consumption levels is shown in Table 10. Residents of the capital city, Seoul, have higher income and consumption levels and thus SSD both other province aggregates. Highly urbanized provinces outside Seoul further SSD less urbanized provinces. When conditioning however on household characteristics, the effects become insignificant.

\section{j) Comparison by health of household head}

That health and income are highly correlated has been shown for many countries. Table 11 provides empirical evidence on their relationship for Korea. A clear ordering can be found for disposable income, i.e. the better the health of the household head the higher is per-capita income. The effect is somewhat less significant, but still evident in the 
ordering of consumption expenditure. Ceteris paribus, households whose heads report "poor" or "very poor" health consume on a significantly lower level than the rest.

\section{Conclusions}

In this paper we consider statistical test procedures for first and second order stochastic dominance. Based on our implementation of the KS-type first and second order stochastic dominance tests, we have been able to show a number of cases of dominance between unconditional as well as conditional distributions of disposable income and consumption expenditure. The dominance ranking over time can be mainly attributed to the effects of the Asian financial crisis and post-crisis productivity improvements. These rankings are in addition impacted by many other factors that may explain income and consumption differentials between different population subgroups. For matters of sensitivity, ceteris paribus examination is offered here by conducting stochastic dominance tests for incomes and expenditures of different groups of households identified by their common characteristics, including head's age, gender, education, occupation, marital status, health status, degree of urbanization and household type and size.

The exercise has shown that, the potential for conducting meaningful statistical rankings of welfare situations based on KLIPS data is good. Previous studies suggest that bootstrap is an attractive alternative to the existing approximate asymptotic inference methods. The bootstrap can be profitably used in the difficult case of inequality restrictions, such as stochastic dominance relations, where even asymptotic approximations are difficult. The use of unrestricted bootstrap confidence intervals in our inferences is a useful innovation when it is difficult to impose the null restrictions in nonparametric settings. The statistical ranking is sound and decisive in many cases. The comparison of the distribution of income and expenditure variables in our study allows a detailed look at the Korean welfare distribution. Several population subgroups are studied separately and in comparison with others.

Our results suggest that although the sample of households studied is small, we observe some clear patterns of economic well-being across household groups and time. 
While first order dominance is very rare, second order dominance holds in many cases. An extension of the sample to incorporate larger and more specific groups of individuals like elderly people targeted for various public transfer policy measures would shed additional light on the state of welfare of households and the impact of those policies implemented. This is important in the design and evaluation of welfare programs targeting vulnerable groups in Korea. Redistribution policies can be effective measures in reducing inequality in disposable income and consumption expenditures. Public efforts to raise the welfare of specific groups such as elderly households, those with less educational credentials, those headed by divorced or widowed females, those residing in less urbanized areas, and those burdened with health problems should be in the center of an effective Korean welfare system. 


\section{Acknowledgements}

We would like to thank Esfandiar Maasoumi, Sung-jin Kang, Sandip Sarkar, Won-Sub Kim and the participants of the ADB/Sogang University conference "Poverty Reduction in Asia: Drivers, Best Practices and Policy Initiatives” for their helpful comments and discussion. 


\section{References}

Adelman, I., and S. Robinson (1978). Income distribution policy in developing countries: A case study of Korea. Stanford University Press, Stanford, and The World Bank, Washington, D.C.

Aguiar, M. A. and M. Bils (2011). Has consumption inequality mirrored income inequality? (No. w16807). National Bureau of Economic Research.

Alesina, A. and R. Perotti (1996). Income distribution, political instability, and investment. European Economic Review, 40(6): 1203-1228.

Anderson, G.J. (1996), Nonparametric Tests of Stochastic Dominance in Income Distributions, Econometrica, 64(5): 1183-1193.

Banerjee, A. V. and E. Duflo (2003). Inequality and growth: what can the data say? Journal of Economic Growth, 8(3): 267-299.

Barrett, G. and Donald, S. (2003), Consistent Tests for Stochastic Dominance, Econometrica, 71(1): 71-104.

Barro, R. J. (2000). Inequality and Growth in a Panel of Countries. Journal of Economic Growth, 5(1): 5-32.

Bishop, J.A., Formby, J.P. and Thisle, P.D. (1992), Convergence of the South and NonSouth Income Distributions, 1969-1979, American Economic Review, 82: 262-272.

Cain, J. C., Hasan, R., and R. Magsombol (2011). Inequality and Poverty in Asia. In: Zhuang, J. (ed.). Poverty, Inequality, and Inclusive Growth in Asia. Anthem Press and Asian Development Bank, 35-85.

Castello-Climent, A. (2010). Inequality and growth in advanced economies: an empirical investigation. The Journal of Economic Inequality, 8(3): 293-321.

Cheong, Kwang-Soo (2001). Economic Crisis and Income Inequality in Korea. Asian Economic Journal, 15(1), 39-60.

Chernozhukov, V. (2002). Inference on Quantile Regression Process, an Alternative, Working Paper, MIT.

Chong, A. and M. Gradstein (2007). Inequality and institutions. The Review of Economics and Statistics, 89(3): 454-465.

Clark, A. E., Frijters, P., and M. A. Shields (2008). Relative income, happiness, and utility: An explanation for the Easterlin paradox and other puzzles. Journal of Economic Literature, 46(1): 95-144.

Crawford, I. (1999), Nonparametric Tests of Stochastic Dominance in Bivariate Distributions with an Application to UK Data, Institute for Fiscal Studies, WP 28/99.

Cummins, R. A. (2000). Personal income and subjective well-being: A review. Journal of Happiness Studies, 1(2): 133-158.

Dardanoni, V. and Forcina, A. (2000), Inference for Lorenz Curve Orderings, Econometrics Journal 2: 49-75.

Davidson, R. and Duclos, J.Y. (2000), Statistical Inference for Stochastic Dominance and for the Measurement of Poverty and Inequality, Econometrica, 68(6): 1435-1464.

Deaton, A. and C. H. Paxson (1994). Intertemporal Choice and Inequality. Journal of Political Economy, 102(3): 437-67. 
Deaton, A. (1997). The Analysis of Household Surveys. A Microeconometric Approach to Development Policy. IBRD, World Bank \& Johns Hopkins University Press.

Deininger, K. and L. Squire (1998). New ways of looking at old issues: inequality and growth. Journal of Development Economics, 57(2): 259-287.

Diener, E., Sandvik, E., Seidlitz, L., and M. Diener (1993). The relationship between income and subjective well-being: Relative or absolute? Social Indicators Research, 28(3): 195-223.

Domeij, D. and M. Floden (2010). Inequality trends in Sweden 1978-2004. Review of Economic Dynamics, 13(1): 179-208.

Fields, G. S., and G. Yoo (2000). Falling labor income inequality in Korea's economic growth: Patterns and underlying causes. Review of Income and Wealth, 46(2), 139-59.

Fisher, G., Wilson, D. and Xu, K. (1998), An Empirical Analysis of Term Premiums Using Significance Tests for Stochastic Dominance, Economics Letters, 60: 195-203.

Friedman, M. (1957). A theory of the consumption function. Princeton University Press.

Hansen, B.E. (1996), Inference when a Nuisance Parameter is not Identified under the Null Hypothesis, Econometrica, 64(2): 413-430.

Heathcote, J., Perri, F., and G. L. Violante (2010). Unequal we stand: An empirical analysis of economic inequality in the United States, 1967-2006. Review of Economic Dynamics, 13(1): 15-51.

Herzer, D. and Vollmer, S. (2012). Inequality and growth: evidence from panel cointegration. The Journal of Economic Inequality, 10(4): 489-503.

Hong, B. E. and H. Y. Kim (2012). Trends of Income Inequality Among the Elderly in Korea. Asian Social Work and Policy Review, 6, 40-55.

Japelli, T. and L. Pistaferri (2010). Does consumption inequality track income inequality in Italy? Review of Economic Dynamics, 13(1): 133-53.

Japelli, T. and L. Pistaferri (2011). Financial integration and consumption smoothing. The Economic Journal, 121(553): 678-706.

Kahneman, D. and A. Deaton (2010). High income improves evaluation of life but not emotional well-being. Proceedings of the National Academy of Sciences, 107(38): 16489-16493.

Kang S.-J. (2010), The Analysis on the Determinants of Life Satisfaction in Korea. Kyongjehak Yongu, 58(1): 5-36 (in Korean).

Kaur, A., Prakasa Rao, B.L.S. and Singh H. (1994), Testing for Second-Order Stochastic Dominance of Two Distributions, Econometric Theory, 10(5): 849-866.

Klecan, L., McFadden, R. and McFadden, D. (1991), A Robust Test for Stochastic Dominance, Working Paper, Department of Economics, MIT.

Krueger, D. and F. Perri (2006). Does income inequality lead to consumption inequality? Evidence and theory. The Review of Economic Studies, 73(1): 163-193.

Linton, O., Maasoumi, E. and Whang, Y.J. (2005), Consistent Testing for Stochastic Dominance under General Sampling Schemes, Review Of Economic Studies, 72(3): 735-765.

Maasoumi, E. (2001), Parametric and Nonparametric Tests of Limited Domain and Ordered Hypotheses in Economics, Chapter 25, in B. Baltagi (ed.) A Companion to Econometric Theory, London: Basil Blackwell. 
Maasoumi E. and A. Heshmati (2000), Stochastic Dominance Amongst Swedish Income Distributions, Econometric Reviews, 19(3): 287-320.

Maasoumi E. and A. Heshmati (2008), Evaluating Dominance Ranking of PSID Incomes by Various Household Attributes, in Gianni Betti and Achille Lemmi, Eds., Advances on income inequality and concentration measures: Collected papers in memory of Corrado Gini and Max O. Lorenz, Chapter 4, pp. 47-69. Routledge Frontiers of Political Economy.

Maasoumi, E. and S. Zandvakili (1990). Generalized Entropy Measures of Mobility for Different Sexes and Income Levels, Journal of Econometrics, 43(1-2): 121-133.

McBride, M. (2001). Relative-income effects on subjective well-being in the cross-section. Journal of Economic Behavior \& Organization, 45(3): 251-278.

McFadden, D. (1989), Testing for Stochastic Dominance, in Part II of T. Fromby 68 Theory and methods and T.K. Seo (eds.) Studies in the Economics of Uncertainty (in honor of J. Hadar), Berlin: Springer-Verlag.

OECD (2011). Society at a Glance 2011: OECD Social Indicators. OECD Publishing. http://dx.doi.org/10.1787/soc_glance-2011-en

OECD (2013). OECD Statistics. http://stats.oecd.org/

Rudolf, R. and S.-J. Kang (2014). Lags and leads in life satisfaction: what changes under gender inequality? Feminist Economics, 20(2).

Rudolf, R. and S.-J. Kang (2013). Rising or Falling Inequality in Korea? Population Aging and Generational Trends. Working Paper, Korea University.

Shorrocks A. and Foster, J. (1987), Transfer Sensitive Inequality Measures, Review of Economic Studies, 54(3): 485-497.

Subramanyam, M., Kawachi, I., Berkman, L., and S. V. Subramanian (2009). Relative deprivation in income and self-rated health in the United States. Social Science \& Medicine, 69(3): 327-334.

Tse, Y.K. and Zhang, X.B. (2000), A Monte Carlo Investigation of Some Tests for Stochastic Dominance, Unpublished Manuscript, National University of Singapore.

UNDP. 2005. Korean Human Development Report on Gender.

Villaverde, J. and A. Maza (2012). Chinese per Capita Income Distribution, 1992-2007: A Regional Perspective. Asian Economic Journal, 26(4), 313-331.

World Economic Forum (WEF). 2010. The Global Gender Gap Report 2010.

Whitmore, G.A. and Findley, M.C. (1978), Stochastic Dominance: An Approach to Decision-Making under Risk, Heath, Lexington: Mars.

Xue, J. and W. Zhong (2003). Unemployment, Poverty and Income Disparity in Urban China. Asian Economic Journal, 17(4), 383-405.

Zhong, H. (2011). The impact of population aging on income inequality in developing countries: Evidence from rural China. China Economic Review, 22(1): 98-107. 


\section{Tables and Figures}

\section{Table 1: Disposable Income and Consumption Expenditure by Household Attribute}

\begin{tabular}{|c|c|c|c|c|c|c|c|c|}
\hline \multirow[t]{2}{*}{ Variable } & \multirow[t]{2}{*}{ Values/Categories } & \multirow[t]{2}{*}{$\mathrm{N}$} & \multicolumn{3}{|c|}{ Disposable Income } & \multicolumn{2}{|c|}{$\begin{array}{l}\text { Consumption } \\
\text { expenditure }\end{array}$} & \multirow[b]{2}{*}{$\mathrm{CV}$} \\
\hline & & & Mean & SD & $\mathrm{CV}$ & Mean & SD & \\
\hline \multirow[t]{4}{*}{ Year } & 1999 & 2993 & 529 & 550 & 1.04 & 358 & 223 & 0.62 \\
\hline & 2002 & 2993 & 679 & 848 & 1.25 & 446 & 268 & 0.60 \\
\hline & 2005 & 2993 & 739 & 851 & 1.15 & 516 & 287 & 0.56 \\
\hline & 2008 & 2993 & 847 & 826 & 0.98 & 544 & 322 & 0.59 \\
\hline \multicolumn{9}{|c|}{ Household characteristics } \\
\hline \multirow[t]{5}{*}{ Household size } & 1 & 369 & 610 & 712 & 1.17 & 478 & 308 & 0.64 \\
\hline & 2 & 587 & 640 & 548 & 0.86 & 449 & 241 & 0.54 \\
\hline & 3 & 605 & 755 & 556 & 0.74 & 470 & 205 & 0.44 \\
\hline & 4 & 1053 & 754 & 470 & 0.62 & 488 & 206 & 0.42 \\
\hline & $\geq 5$ & 379 & 631 & 430 & 0.68 & 410 & 160 & 0.39 \\
\hline \multirow[t]{5}{*}{ Household type } & single & 368 & 611 & 712 & 1.16 & 479 & 308 & 0.64 \\
\hline & married w/o children & 341 & 677 & 561 & 0.83 & 471 & 268 & 0.57 \\
\hline & married w/ children & 828 & 778 & 507 & 0.65 & 498 & 205 & 0.41 \\
\hline & single with elderly & 210 & 600 & 578 & 0.96 & 404 & 206 & 0.51 \\
\hline & other & 1246 & 694 & 473 & 0.68 & 449 & 191 & 0.42 \\
\hline \multirow{3}{*}{$\begin{array}{l}\text { Province of } \\
\text { residence }\end{array}$} & Capital & 635 & 787 & 593 & 0.75 & 514 & 254 & 0.49 \\
\hline & Highly urbanized $^{3}$ & 1486 & 709 & 535 & 0.76 & 477 & 223 & 0.47 \\
\hline & Less urbanized ${ }^{4}$ & 872 & 617 & 485 & 0.79 & 411 & 191 & 0.46 \\
\hline \multicolumn{9}{|c|}{ Head characteristics } \\
\hline \multirow[t]{5}{*}{ Age } & age $\leq 30$ & 178 & 593 & 298 & 0.50 & 415 & 133 & 0.32 \\
\hline & $30<$ age $\leq 40$ & 401 & 808 & 528 & 0.65 & 480 & 199 & 0.41 \\
\hline & $40<$ age $\leq 50$ & 865 & 732 & 496 & 0.68 & 483 & 225 & 0.47 \\
\hline & $50<$ age $\leq 65$ & 880 & 816 & 596 & 0.73 & 519 & 246 & 0.47 \\
\hline & age $\geq 65$ & 669 & 464 & 483 & 1.04 & 378 & 197 & 0.52 \\
\hline \multirow[t]{2}{*}{ Sex } & female & 765 & 573 & 537 & 0.94 & 418 & 224 & 0.54 \\
\hline & male & 2228 & 742 & 531 & 0.72 & 482 & 222 & 0.46 \\
\hline \multirow{5}{*}{$\begin{array}{l}\text { Years of } \\
\text { schooling }\end{array}$} & no schooling & 176 & 284 & 317 & 1.12 & 282 & 114 & 0.41 \\
\hline & up to 6 years & 494 & 484 & 382 & 0.79 & 360 & 140 & 0.39 \\
\hline & up to 9 years & 426 & 591 & 412 & 0.70 & 419 & 160 & 0.38 \\
\hline & up to 12 years & 1033 & 714 & 491 & 0.69 & 465 & 183 & 0.39 \\
\hline & more than 12 years & 864 & 940 & 632 & 0.67 & 587 & 280 & 0.48 \\
\hline \multirow[t]{3}{*}{ Marital status } & never married & 376 & 732 & 502 & 0.69 & 476 & 246 & 0.52 \\
\hline & married & 2040 & 756 & 542 & 0.72 & 486 & 224 & 0.46 \\
\hline & sep./div./wid. & 577 & 472 & 481 & 1.02 & 387 & 191 & 0.49 \\
\hline Health & poor/very poor & 577 & 430 & 382 & 0.89 & 361 & 180 & 0.50 \\
\hline
\end{tabular}




\begin{tabular}{lllllllll} 
& fair & 801 & 660 & 480 & 0.73 & 455 & 202 & 0.44 \\
& excellent/good & 1592 & 815 & 571 & 0.70 & 509 & 236 & 0.46 \\
Occupation & & & & & & & \\
& $\begin{array}{l}\text { Professionals } \\
\text { Service sector }\end{array}$ & 647 & 952 & 624 & 0.66 & 596 & 271 & 0.45 \\
& $\begin{array}{l}\text { Agriculture \& } \\
\text { handicrafts }\end{array}$ & 724 & 599 & 469 & 0.78 & 406 & 171 & 0.42 \\
\hline \hline
\end{tabular}

Notes: All monetary figures are real per-capita average monthly values in thousands of Korean Won using provincial CPIs with base year 2005. "'Highly urbanized" includes Busan, Daegu, Daejeon, Incheon, Gwangju, Ulsan, Gyeonggi-do.

2"Less urbanized" includes Gangwon-do, Chungcheonbuk-do, Chungcheonnam-do, Jeollabuk-do, Jeollanam-do,

Gyeongsangbuk-do, Gyeongsangnam-do and Jeju-do. 
Table 2: Comparison of disposable income and consumption expenditure by YEAR of observation

\begin{tabular}{|c|c|c|c|c|c|c|c|c|c|c|c|c|}
\hline \multirow[b]{3}{*}{ variable } & \multicolumn{6}{|c|}{ unconditional (level) } & \multicolumn{6}{|c|}{ conditional (residual) } \\
\hline & \multicolumn{3}{|c|}{ disposable income } & \multicolumn{3}{|c|}{ consumption expenditure } & \multicolumn{3}{|c|}{ disposable income } & \multicolumn{3}{|c|}{ consumption expenditure } \\
\hline & mean & std & prob & mean & std & prob & mean & std & prob & mean & std & prob \\
\hline \multicolumn{13}{|c|}{ 1999(x) vs. 2002(y) } \\
\hline FSDxoy & 0.0814 & 0.0103 & 0.000 & 0.1644 & 0.0124 & 0.000 & 0.1162 & 0.0123 & 0.000 & 0.1705 & 0.0126 & 0.000 \\
\hline FSDyox & -0.0002 & 0.0005 & 0.656 & 0.0000 & 0.0001 & 0.327 & -0.0001 & 0.0005 & 0.595 & 0.0005 & 0.0005 & 0.139 \\
\hline FOmax & -0.0002 & 0.0005 & 0.656 & 0.0000 & 0.0001 & 0.327 & -0.0001 & 0.0005 & 0.595 & 0.0005 & 0.0005 & 0.139 \\
\hline SSDxoy & 0.1371 & 0.0211 & 0.000 & 0.5431 & 0.0433 & 0.000 & 0.1719 & 0.0212 & 0.000 & 0.5253 & 0.0387 & 0.000 \\
\hline SSDyox & -0.0814 & 0.0103 & 1.000 & -0.0445 & 0.0061 & 1.000 & -0.1162 & 0.0123 & 1.000 & -0.0064 & 0.0031 & 0.984 \\
\hline SOmax & -0.0814 & 0.0103 & 1.000 & -0.0445 & 0.0061 & 1.000 & -0.1162 & 0.0123 & 1.000 & -0.0064 & 0.0031 & 0.984 \\
\hline \multicolumn{13}{|c|}{ 1999(x) vs. 2005(y) } \\
\hline FSDxoy & 0.0924 & 0.0092 & 0.000 & 0.3012 & 0.0118 & 0.000 & 0.0425 & 0.0097 & 0.000 & 0.1242 & 0.0113 & 0.000 \\
\hline FSDyox & -0.0001 & 0.0005 & 0.536 & 0.0003 & 0.0003 & 0.123 & -0.0001 & 0.0005 & 0.611 & 0.0026 & 0.0023 & 0.011 \\
\hline FOmax & -0.0001 & 0.0005 & 0.536 & 0.0003 & 0.0003 & 0.123 & -0.0001 & 0.0005 & 0.611 & 0.0026 & 0.0023 & 0.011 \\
\hline SSDxoy & 0.1411 & 0.0169 & 0.000 & 1.1262 & 0.0456 & 0.000 & 0.0763 & 0.0166 & 0.000 & 0.4005 & 0.0404 & 0.000 \\
\hline SSDyox & -0.0924 & 0.0092 & 1.000 & -0.0640 & 0.0056 & 1.000 & -0.0425 & 0.0097 & 1.000 & 0.0016 & 0.0036 & 0.279 \\
\hline SOmax & -0.0924 & 0.0092 & 1.000 & -0.0640 & 0.0056 & 1.000 & -0.0425 & 0.0097 & 1.000 & 0.0016 & 0.0036 & 0.279 \\
\hline \multicolumn{13}{|c|}{ 1999(x) vs. 2008(y) } \\
\hline FSDxoy & 0.2507 & 0.0123 & 0.000 & 0.3754 & 0.0119 & 0.000 & 0.0675 & 0.0082 & 0.000 & 0.1496 & 0.0103 & 0.000 \\
\hline FSDyox & -0.0001 & 0.0005 & 0.564 & 0.0001 & 0.0002 & 0.259 & 0.0001 & 0.0006 & 0.461 & 0.0002 & 0.0012 & 0.515 \\
\hline FOmax & -0.0001 & 0.0005 & 0.564 & 0.0001 & 0.0002 & 0.259 & 0.0001 & 0.0006 & 0.461 & 0.0002 & 0.0012 & 0.515 \\
\hline SSDxoy & 0.4359 & 0.0270 & 0.000 & 0.9216 & 0.0337 & 0.000 & 0.1778 & 0.0259 & 0.000 & 0.3766 & 0.0298 & 0.000 \\
\hline SSDyox & -0.2507 & 0.0123 & 1.000 & -0.1659 & 0.0088 & 1.000 & -0.0379 & 0.0126 & 0.999 & -0.0064 & 0.0053 & 0.881 \\
\hline SOmax & -0.2507 & 0.0123 & 1.000 & -0.1659 & 0.0088 & 1.000 & -0.0379 & 0.0126 & 0.999 & -0.0064 & 0.0053 & 0.881 \\
\hline \multicolumn{13}{|c|}{ 2002(x) vs. 2005(y) } \\
\hline FSDxoy & 0.0388 & 0.0097 & 0.000 & 0.1009 & 0.0124 & 0.000 & 0.0024 & 0.0018 & 0.024 & 0.0133 & 0.0077 & 0.007 \\
\hline FSDyox & 0.0016 & 0.0011 & 0.031 & 0.0013 & 0.0011 & 0.031 & 0.0490 & 0.0107 & 0.000 & 0.0866 & 0.0121 & 0.000 \\
\hline FOmax & 0.0016 & 0.0010 & 0.031 & 0.0013 & 0.0011 & 0.031 & 0.0024 & 0.0018 & 0.024 & 0.0133 & 0.0077 & 0.007 \\
\hline SSDxoy & 0.0556 & 0.0167 & 0.000 & 0.4173 & 0.0514 & 0.000 & -0.0431 & 0.0143 & 0.997 & -0.0076 & 0.0031 & 0.989 \\
\hline SSDyox & -0.0356 & 0.0128 & 0.992 & -0.0125 & 0.0038 & 0.999 & 0.0588 & 0.0161 & 0.000 & 0.1572 & 0.0296 & 0.000 \\
\hline SOmax & -0.0357 & 0.0126 & 0.992 & -0.0125 & 0.0038 & 0.999 & -0.0431 & 0.0143 & 0.997 & -0.0076 & 0.0031 & 0.989 \\
\hline
\end{tabular}


2002(x) vs. 2008(y)

\begin{tabular}{lrlllllllllll} 
FSDxoy & 0.1326 & 0.0119 & 0.000 & 0.2068 & 0.0127 & 0.000 & 0.0193 & 0.0060 & 0.000 & 0.0331 & 0.0097 & 0.000 \\
FSDyox & 0.0015 & 0.0008 & 0.006 & 0.0002 & 0.0008 & 0.447 & 0.0154 & 0.0113 & 0.000 & 0.0511 & 0.0121 & 0.000 \\
FOmax & 0.0015 & 0.0008 & 0.006 & 0.0002 & 0.0008 & 0.447 & 0.0112 & 0.0068 & 0.000 & 0.0315 & 0.0082 & 0.000 \\
SSDxoy & 0.1980 & 0.0222 & 0.000 & 0.4674 & 0.0360 & 0.000 & 0.0187 & 0.0201 & 0.178 & 0.0103 & 0.0244 & 0.401 \\
SSDyox & -0.1326 & 0.0119 & $\mathbf{1 . 0 0 0}$ & -0.0341 & 0.0073 & $\mathbf{1 . 0 0 0}$ & 0.0157 & 0.0142 & 0.124 & 0.0674 & 0.0142 & 0.000 \\
SOmax & -0.1326 & 0.0119 & 1.000 & -0.0341 & 0.0073 & 1.000 & 0.0040 & 0.0107 & 0.302 & 0.0093 & 0.0223 & 0.401 \\
2005(x) vs. & $\mathbf{2 0 0 8}(\boldsymbol{y})$ & & & & & & & & & & & \\
FSDxoy & 0.0554 & 0.0107 & 0.000 & 0.0756 & 0.0127 & 0.000 & 0.0637 & 0.0107 & 0.000 & 0.0341 & 0.0106 & 0.000 \\
FSDyox & 0.0014 & 0.0011 & 0.040 & 0.0013 & 0.0023 & 0.356 & 0.0017 & 0.0012 & 0.015 & 0.0016 & 0.0022 & 0.251 \\
FOmax & 0.0014 & 0.0011 & 0.040 & 0.0013 & 0.0023 & 0.356 & 0.0017 & 0.0012 & 0.015 & 0.0015 & 0.0021 & 0.251 \\
SSDxoy & 0.0775 & 0.0175 & 0.000 & 0.1708 & 0.0363 & 0.000 & 0.0834 & 0.0161 & 0.000 & 0.1019 & 0.0309 & 0.000 \\
SSDyox & -0.0543 & 0.0120 & $\mathbf{1 . 0 0 0}$ & -0.0097 & 0.0068 & $\mathbf{0 . 9 2 6}$ & -0.0622 & 0.0123 & $\mathbf{1 . 0 0 0}$ & -0.0066 & 0.0056 & 0.884 \\
SOmax & -0.0543 & 0.0120 & 1.000 & -0.0097 & 0.0068 & 0.926 & -0.0622 & 0.0123 & 1.000 & -0.0067 & 0.0053 & 0.884 \\
\hline \hline
\end{tabular}
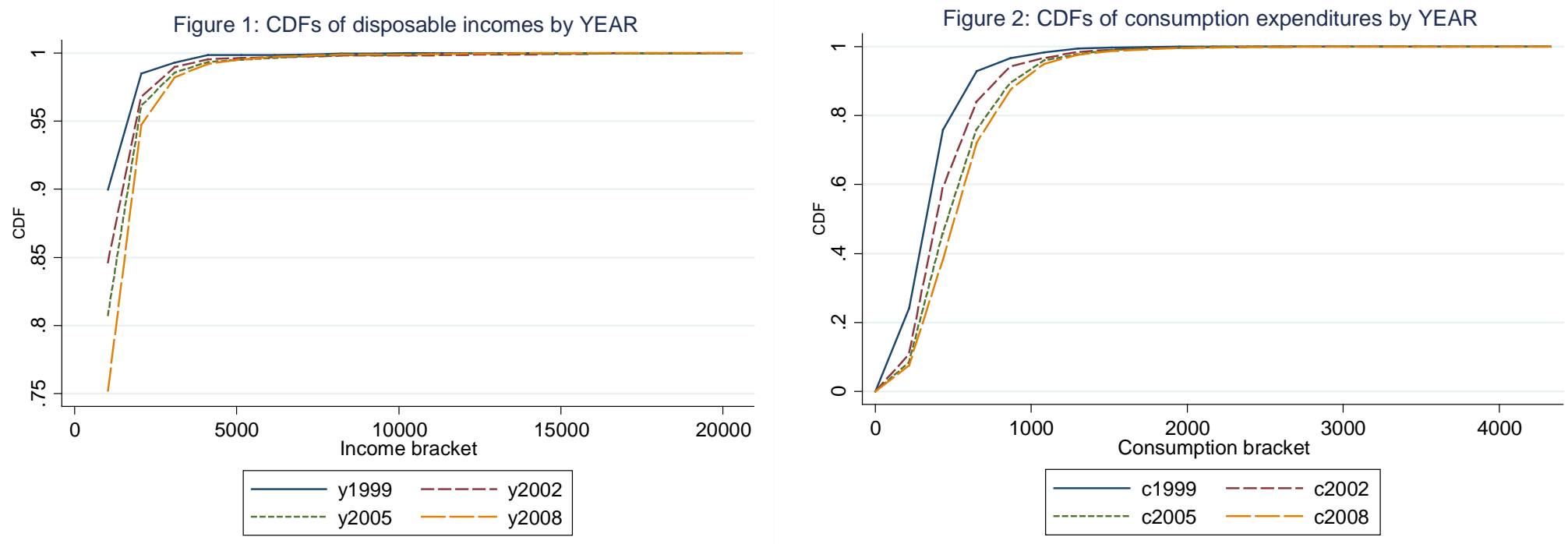
Table 3: Comparison of disposable income and consumption expenditure by HOUSEHOLD SIZE

\begin{tabular}{|c|c|c|c|c|c|c|c|c|c|c|c|c|}
\hline \multirow[b]{3}{*}{ variable } & \multicolumn{6}{|c|}{ unconditional (level) } & \multicolumn{6}{|c|}{ conditional (residual) } \\
\hline & \multicolumn{3}{|c|}{ disposable income } & \multicolumn{3}{|c|}{ consumption expenditure } & \multicolumn{3}{|c|}{ disposable income } & \multicolumn{3}{|c|}{ consumption expenditure } \\
\hline & mean & std & prob & mean & std & prob & mean & std & prob & mean & std & prob \\
\hline \multicolumn{13}{|l|}{$1(x)$ vs. $2(y)$} \\
\hline FSDxoy & 0.1748 & 0.0315 & 0.000 & 0.0351 & 0.0212 & 0.017 & 0.0015 & 0.0024 & 0.151 & 0.0079 & 0.0087 & 0.155 \\
\hline FSDyox & 0.0345 & 0.0164 & 0.000 & 0.0564 & 0.0165 & 0.000 & 0.2736 & 0.0302 & 0.000 & 0.2071 & 0.0303 & 0.000 \\
\hline FOmax & 0.0345 & 0.0164 & 0.000 & 0.0306 & 0.0162 & 0.017 & 0.0015 & 0.0024 & 0.151 & 0.0079 & 0.0087 & 0.155 \\
\hline SSDxoy & 0.3151 & 0.0772 & 0.000 & 0.0692 & 0.0631 & 0.060 & -0.2303 & 0.0263 & 1.000 & 0.0040 & 0.0122 & 0.374 \\
\hline SSDyox & -0.1172 & 0.0951 & 0.877 & 0.1999 & 0.1445 & 0.000 & 0.8493 & 0.1302 & 0.000 & 0.6681 & 0.1277 & 0.000 \\
\hline SOmax & -0.1179 & 0.0924 & 0.877 & 0.0382 & 0.0351 & 0.060 & -0.2303 & 0.0263 & 1.000 & 0.0040 & 0.0122 & 0.374 \\
\hline \multicolumn{13}{|l|}{$1(x)$ vs. $3(y)$} \\
\hline FSDxоy & 0.3161 & 0.0275 & 0.000 & 0.1308 & 0.0291 & 0.000 & 0.0041 & 0.0029 & 0.012 & -0.0023 & 0.0031 & 0.662 \\
\hline FSDyox & 0.0359 & 0.0159 & 0.002 & 0.0628 & 0.0181 & 0.000 & 0.3467 & 0.0271 & 0.000 & 0.3769 & 0.0306 & 0.000 \\
\hline FOmax & 0.0359 & 0.0159 & 0.002 & 0.0624 & 0.0175 & 0.000 & 0.0041 & 0.0029 & 0.012 & -0.0023 & 0.0031 & 0.662 \\
\hline SSDxoy & 0.6897 & 0.0805 & 0.000 & 0.2973 & 0.0794 & 0.000 & -0.3455 & 0.0279 & 1.000 & -0.0619 & 0.0150 & 1.000 \\
\hline SSDyox & -0.3137 & 0.0319 & 1.000 & 0.0753 & 0.0956 & 0.000 & 0.9540 & 0.1133 & 0.000 & 1.3677 & 0.1238 & 0.000 \\
\hline SOmax & -0.3137 & 0.0319 & 1.000 & 0.0645 & 0.0732 & 0.000 & -0.3455 & 0.0279 & 1.000 & -0.0619 & 0.0150 & 1.000 \\
\hline \multicolumn{13}{|l|}{ 1(x) vs. $4(y)$} \\
\hline FSDxоy & 0.3603 & 0.0272 & 0.000 & 0.1902 & 0.0284 & 0.000 & 0.0005 & 0.0009 & 0.109 & 0.0009 & 0.0013 & 0.094 \\
\hline FSDyox & 0.0393 & 0.0154 & 0.000 & 0.0615 & 0.0172 & 0.000 & 0.4955 & 0.0229 & 0.000 & 0.4945 & 0.0260 & 0.000 \\
\hline FOmax & 0.0393 & 0.0154 & 0.000 & 0.0615 & 0.0172 & 0.000 & 0.0005 & 0.0009 & 0.109 & 0.0009 & 0.0013 & 0.094 \\
\hline SSDxоy & 0.7306 & 0.0678 & 0.000 & 0.3801 & 0.0699 & 0.000 & -0.4954 & 0.0230 & 1.000 & -0.1332 & 0.0144 & 1.000 \\
\hline SSDyox & -0.3575 & 0.0330 & 1.000 & 0.0316 & 0.0639 & 0.000 & 1.3718 & 0.1137 & 0.000 & 1.6955 & 0.1107 & 0.000 \\
\hline SOmax & -0.3575 & 0.0330 & 1.000 & 0.0307 & 0.0599 & 0.000 & -0.4954 & 0.0230 & 1.000 & -0.1332 & 0.0144 & 1.000 \\
\hline \multicolumn{13}{|l|}{$1(x)$ vs. $5(y)$} \\
\hline FSDxоy & 0.3065 & 0.0308 & 0.000 & 0.0601 & 0.0205 & 0.000 & 0.0001 & 0.0008 & 0.143 & 0.0000 & 0.0000 & 0.158 \\
\hline FSDyox & 0.0716 & 0.0233 & 0.000 & 0.1177 & 0.0230 & 0.000 & 0.6207 & 0.0279 & 0.000 & 0.5656 & 0.0264 & 0.000 \\
\hline FOmax & 0.0716 & 0.0233 & 0.000 & 0.0596 & 0.0198 & 0.000 & 0.0001 & 0.0008 & 0.143 & 0.0000 & 0.0000 & 0.158 \\
\hline SSDxoy & 0.4433 & 0.0585 & 0.000 & 0.0750 & 0.0411 & 0.007 & -0.6207 & 0.0279 & 1.000 & -0.2584 & 0.0257 & 1.000 \\
\hline SSDyox & -0.1276 & 0.1372 & 0.810 & 0.5776 & 0.1585 & 0.000 & 1.5843 & 0.1298 & 0.000 & 2.0836 & 0.1210 & 0.000 \\
\hline SOmax & -0.1277 & 0.1371 & 0.810 & 0.0746 & 0.0402 & 0.007 & -0.6207 & 0.0279 & 1.000 & -0.2584 & 0.0257 & 1.000 \\
\hline
\end{tabular}


2(x) vs. 3(y)

\begin{tabular}{|c|c|c|c|c|c|c|c|c|c|c|c|c|}
\hline FSDxoy & 0.1612 & 0.0252 & 0.000 & 0.1278 & 0.0271 & 0.000 & 0.0076 & 0.0051 & 0.003 & 0.0007 & 0.0013 & 0.042 \\
\hline FSDyox & 0.0153 & 0.0107 & 0.037 & 0.0293 & 0.0150 & 0.000 & 0.0963 & 0.0268 & 0.000 & 0.1854 & 0.0252 & 0.000 \\
\hline FOmax & 0.0153 & 0.0107 & 0.037 & 0.0292 & 0.0147 & 0.000 & 0.0076 & 0.0051 & 0.003 & 0.0007 & 0.0013 & 0.042 \\
\hline SSDxoy & 0.4151 & 0.0851 & 0.000 & 0.3518 & 0.0926 & 0.000 & -0.0901 & 0.0356 & 0.977 & -0.0324 & 0.0115 & 1.000 \\
\hline SSDyox & -0.1387 & 0.0223 & 1.000 & 0.0057 & 0.0179 & 0.000 & 0.2293 & 0.0752 & 0.000 & 0.8932 & 0.1254 & 0.000 \\
\hline SOmax & -0.1387 & 0.0223 & 1.000 & 0.0053 & 0.0156 & 0.000 & -0.0902 & 0.0352 & 0.977 & -0.0324 & 0.0115 & 1.000 \\
\hline \multicolumn{13}{|c|}{$2(x)$ vs. $4(y)$} \\
\hline FSDxоy & 0.2090 & 0.0240 & 0.000 & 0.1821 & 0.0235 & 0.000 & 0.0022 & 0.0026 & 0.059 & 0.0019 & 0.0014 & 0.020 \\
\hline FSDyox & 0.0189 & 0.0115 & 0.004 & 0.0246 & 0.0133 & 0.000 & 0.2365 & 0.0241 & 0.000 & 0.2975 & 0.0199 & 0.000 \\
\hline FOmax & 0.0189 & 0.0115 & 0.004 & 0.0246 & 0.0133 & 0.000 & 0.0022 & 0.0026 & 0.059 & 0.0019 & 0.0014 & 0.020 \\
\hline SSDxoy & 0.5066 & 0.0701 & 0.000 & 0.4103 & 0.0645 & 0.000 & -0.2365 & 0.0241 & 1.000 & -0.1325 & 0.0132 & 1.000 \\
\hline SSDyox & -0.1603 & 0.0171 & 1.000 & -0.0017 & 0.0017 & 0.610 & 0.5881 & 0.0834 & 0.000 & 1.0601 & 0.0827 & 0.000 \\
\hline SOmax & -0.1603 & 0.0171 & 1.000 & -0.0017 & 0.0017 & 0.610 & -0.2365 & 0.0241 & 1.000 & -0.1325 & 0.0132 & 1.000 \\
\hline \multicolumn{13}{|c|}{$2(x)$ vs. $5(y)$} \\
\hline FSDxoy & 0.1199 & 0.0207 & 0.000 & 0.0465 & 0.0233 & 0.008 & 0.0031 & 0.0040 & 0.044 & 0.0000 & 0.0000 & 0.059 \\
\hline FSDyox & 0.0611 & 0.0234 & 0.000 & 0.0914 & 0.0197 & 0.000 & 0.3713 & 0.0300 & 0.000 & 0.4592 & 0.0283 & 0.000 \\
\hline FOmax & 0.0603 & 0.0224 & 0.000 & 0.0449 & 0.0209 & 0.008 & 0.0031 & 0.0040 & 0.044 & 0.0000 & 0.0000 & 0.059 \\
\hline SSDxoy & 0.1898 & 0.0484 & 0.000 & 0.0696 & 0.0426 & 0.032 & -0.3713 & 0.0300 & 1.000 & -0.2168 & 0.0225 & 1.000 \\
\hline SSDyox & 0.0336 & 0.1174 & 0.423 & 0.3929 & 0.1456 & 0.000 & 0.8221 & 0.1038 & 0.000 & 1.8953 & 0.1185 & 0.000 \\
\hline SOmax & 0.0197 & 0.0954 & 0.423 & 0.0668 & 0.0386 & 0.032 & -0.3713 & 0.0300 & 1.000 & -0.2168 & 0.0225 & 1.000 \\
\hline \multicolumn{13}{|c|}{$3(x)$ vs. $4(y)]$} \\
\hline FSDxoy & 0.0398 & 0.0134 & 0.000 & 0.0515 & 0.0182 & 0.000 & 0.0022 & 0.0036 & 0.272 & 0.0064 & 0.0044 & 0.016 \\
\hline FSDyox & 0.0190 & 0.0134 & 0.002 & 0.0143 & 0.0122 & 0.013 & 0.1539 & 0.0243 & 0.000 & 0.1179 & 0.0218 & 0.000 \\
\hline FOmax & 0.0167 & 0.0105 & 0.002 & 0.0134 & 0.0107 & 0.013 & 0.0022 & 0.0036 & 0.272 & 0.0064 & 0.0044 & 0.016 \\
\hline SSDxоy & 0.0779 & 0.0497 & 0.000 & 0.1362 & 0.0642 & 0.000 & -0.1537 & 0.0246 & 1.000 & -0.0665 & 0.0168 & 1.000 \\
\hline SSDyox & 0.0136 & 0.0622 & 0.524 & 0.0005 & 0.0186 & 0.832 & 0.3192 & 0.0727 & 0.000 & 0.3769 & 0.0709 & 0.000 \\
\hline SOmax & -0.0039 & 0.0358 & 0.524 & -0.0008 & 0.0132 & 0.832 & -0.1537 & 0.0246 & 1.000 & -0.0665 & 0.0168 & 1.000 \\
\hline \multicolumn{13}{|c|}{$3(x)$ vs. $5(y)$} \\
\hline FSDxoy & 0.0063 & 0.0083 & 0.219 & 0.0083 & 0.0082 & 0.103 & 0.0029 & 0.0044 & 0.246 & 0.0007 & 0.0020 & 0.396 \\
\hline FSDyox & 0.1490 & 0.0264 & 0.000 & 0.1458 & 0.0301 & 0.000 & 0.2603 & 0.0297 & 0.000 & 0.2809 & 0.0286 & 0.000 \\
\hline FOmax & 0.0063 & 0.0083 & 0.219 & 0.0083 & 0.0082 & 0.103 & 0.0029 & 0.0044 & 0.246 & 0.0007 & 0.0020 & 0.396 \\
\hline SSDxoy & -0.0112 & 0.0192 & 0.727 & 0.0022 & 0.0114 & 0.480 & -0.2602 & 0.0297 & 1.000 & -0.1589 & 0.0246 & 1.000 \\
\hline SSDyox & 0.4239 & 0.1059 & 0.000 & 0.6116 & 0.1269 & 0.000 & 0.4887 & 0.0863 & 0.000 & 1.1736 & 0.1120 & 0.000 \\
\hline SOmax & -0.0112 & 0.0192 & 0.727 & 0.0022 & 0.0114 & 0.480 & -0.2602 & 0.0297 & 1.000 & -0.1589 & 0.0246 & 1.000 \\
\hline
\end{tabular}


$4(x)$ vs. $5(y)$

FSDxoy

$\begin{array}{lll}0.0063 & 0.0064 & 0.058 \\ 0.1601 & 0.0250 & 0.000\end{array}$

FSDyox

$\begin{array}{lll}0.0063 & 0.0064 & 0.058\end{array}$

$\begin{array}{lll}-0.0315 & 0.0136 & \mathbf{0 . 9 9 6}\end{array}$

SSDxoy

$\begin{array}{lll}0.4937 & 0.0960 \quad 0.000\end{array}$

$\begin{array}{lll}-0.0315 & 0.0136 \quad 0.996\end{array}$

$\begin{array}{rrr}0.0001 & 0.0006 & 0.281 \\ 0.1910 & 0.0273 & 0.000 \\ 0.0001 & 0.0006 & 0.281 \\ -0.0079 & 0.0046 & \mathbf{0 . 9 6 1} \\ 0.6466 & 0.0870 & 0.000 \\ -0.0079 & 0.0046 & 0.961\end{array}$

$\begin{array}{rrr}0.0067 & 0.0065 & 0.049 \\ 0.1378 & 0.0276 & 0.000 \\ 0.0067 & 0.0065 & 0.049 \\ -0.1350 & 0.0326 & \mathbf{0 . 9 9 8} \\ 0.2657 & 0.0717 & 0.000 \\ -0.1350 & 0.0326 & 0.998\end{array}$

0.0003

$0.0016 \quad 0.268$

$\begin{array}{lll}0.1513 & 0.0280 & 0.000\end{array}$

$\begin{array}{lll}0.0003 & 0.0016 & 0.268\end{array}$

$\begin{array}{lll}-0.1116 & 0.0258 & \mathbf{1 . 0 0 0}\end{array}$

SOmax

$-0.0079$

$-0.1350$

0.4691

$0.0766 \quad 0.000$

SOmax 
Table 4: Comparison of disposable income and consumption expenditure by AGE of household head

\begin{tabular}{|c|c|c|c|c|c|c|c|c|c|c|c|c|}
\hline \multirow[b]{3}{*}{ variable } & \multicolumn{6}{|c|}{ unconditional (level) } & \multicolumn{6}{|c|}{ conditional (residual) } \\
\hline & \multicolumn{3}{|c|}{ disposable income } & \multicolumn{3}{|c|}{ consumption expenditure } & \multicolumn{3}{|c|}{ disposable income } & \multicolumn{3}{|c|}{ consumption expenditure } \\
\hline & mean & std & prob & mean & std & prob & mean & std & prob & mean & std & prob \\
\hline \multicolumn{13}{|c|}{ age $\leq 30(x)$ vs. $31-40(y)$} \\
\hline FSDxoy & 0.1984 & 0.0356 & 0.000 & 0.1608 & 0.0345 & 0.000 & 0.0918 & 0.0316 & 0.000 & 0.0373 & 0.0167 & 0.000 \\
\hline FSDyox & 0.0000 & 0.0004 & 0.498 & 0.0104 & 0.0152 & 0.000 & 0.0177 & 0.0170 & 0.053 & 0.1765 & 0.0421 & 0.000 \\
\hline FOmax & 0.0000 & 0.0004 & 0.498 & 0.0104 & 0.0152 & 0.000 & 0.0173 & 0.0160 & 0.053 & 0.0373 & 0.0167 & 0.000 \\
\hline SSDxoy & 0.7326 & 0.1174 & 0.000 & 1.0363 & 0.2213 & 0.000 & 0.2564 & 0.1065 & 0.002 & 0.0021 & 0.0076 & 0.000 \\
\hline SSDyox & -0.0658 & 0.0258 & 0.996 & 0.0055 & 0.0133 & 0.000 & 0.0213 & 0.0247 & 0.152 & 0.7291 & 0.1896 & 0.000 \\
\hline SOmax & -0.0658 & 0.0258 & 0.996 & 0.0055 & 0.0133 & 0.000 & 0.0197 & 0.0213 & 0.154 & 0.0020 & 0.0072 & 0.000 \\
\hline \multicolumn{13}{|c|}{ age $\leq 30(x)$ vs. $41-50(y)$} \\
\hline FSDxoy & 0.1315 & 0.0327 & 0.000 & 0.1475 & 0.0346 & 0.000 & 0.1524 & 0.0341 & 0.000 & 0.1105 & 0.0262 & 0.000 \\
\hline FSDyox & 0.0013 & 0.0058 & 0.152 & 0.0092 & 0.0116 & 0.179 & 0.0028 & 0.0037 & 0.077 & 0.0177 & 0.0190 & 0.000 \\
\hline FOmax & 0.0013 & 0.0058 & 0.152 & 0.0092 & 0.0116 & 0.179 & 0.0028 & 0.0037 & 0.077 & 0.0176 & 0.0187 & 0.000 \\
\hline SSDxoy & 0.5720 & 0.1163 & 0.000 & 0.5396 & 0.1099 & 0.000 & 0.5864 & 0.1143 & 0.000 & 0.3268 & 0.0992 & 0.000 \\
\hline SSDyox & -0.0406 & 0.0232 & 0.962 & 0.0055 & 0.0151 & 0.376 & 0.0005 & 0.0062 & 0.408 & 0.0218 & 0.0284 & 0.000 \\
\hline SOmax & -0.0406 & 0.0232 & 0.962 & 0.0055 & 0.0151 & 0.376 & 0.0005 & 0.0062 & 0.408 & 0.0213 & 0.0269 & 0.000 \\
\hline \multicolumn{13}{|c|}{ age $\leq 30(x)$ vs. 51-65(y) } \\
\hline FSDxoy & 0.1858 & 0.0352 & 0.000 & 0.2219 & 0.0334 & 0.000 & 0.2391 & 0.0373 & 0.000 & 0.2560 & 0.0294 & 0.000 \\
\hline FSDyox & 0.0000 & 0.0048 & 0.636 & 0.0104 & 0.0094 & 0.000 & 0.0034 & 0.0046 & 0.066 & 0.0044 & 0.0034 & 0.000 \\
\hline FOmax & 0.0000 & 0.0048 & 0.636 & 0.0104 & 0.0094 & 0.000 & 0.0034 & 0.0046 & 0.066 & 0.0044 & 0.0034 & 0.000 \\
\hline SSDxoy & 0.7847 & 0.1083 & 0.000 & 0.9701 & 0.1284 & 0.000 & 0.8216 & 0.1007 & 0.000 & 1.0428 & 0.1183 & 0.000 \\
\hline SSDyox & -0.0334 & 0.0251 & 0.914 & 0.0115 & 0.0116 & 0.000 & -0.0001 & 0.0088 & 0.459 & 0.0055 & 0.0049 & 0.000 \\
\hline SOmax & -0.0334 & 0.0251 & 0.914 & 0.0115 & 0.0116 & 0.000 & -0.0001 & 0.0088 & 0.459 & 0.0055 & 0.0049 & 0.000 \\
\hline \multicolumn{13}{|c|}{ age $\leq 30(x)$ vs. age $\geq 65(y)$} \\
\hline FSDxоy & 0.0212 & 0.0077 & 0.000 & 0.0416 & 0.0176 & 0.000 & 0.0224 & 0.0091 & 0.000 & 0.0470 & 0.0189 & 0.000 \\
\hline FSDyox & 0.3159 & 0.0373 & 0.000 & 0.2472 & 0.0320 & 0.000 & 0.1210 & 0.0393 & 0.000 & 0.1951 & 0.0389 & 0.000 \\
\hline FOmax & 0.0212 & 0.0077 & 0.000 & 0.0416 & 0.0176 & 0.000 & 0.0223 & 0.0089 & 0.000 & 0.0470 & 0.0189 & 0.000 \\
\hline SSDxoy & -0.2626 & 0.0272 & 1.000 & 0.0000 & 0.0004 & 0.000 & -0.0025 & 0.0314 & 0.796 & -0.0012 & 0.0023 & 0.624 \\
\hline SSDyox & 0.6985 & 0.0921 & 0.000 & 0.7020 & 0.1115 & 0.000 & 0.2127 & 0.0779 & 0.000 & 0.5642 & 0.1102 & 0.000 \\
\hline SOmax & -0.2626 & 0.0272 & 1.000 & 0.0000 & 0.0004 & 0.000 & -0.0040 & 0.0257 & 0.796 & -0.0012 & 0.0023 & 0.624 \\
\hline
\end{tabular}


31-40(x) vs. 41-50(y)

\begin{tabular}{|c|c|c|c|c|c|c|c|c|c|c|c|c|}
\hline FSDxoy & 0.0121 & 0.0078 & 0.001 & 0.0223 & 0.0171 & 0.001 & 0.0859 & 0.0280 & 0.000 & 0.1875 & 0.0286 & 0.000 \\
\hline FSDyox & 0.0884 & 0.0278 & 0.000 & 0.0373 & 0.0190 & 0.000 & 0.0102 & 0.0109 & 0.001 & 0.0023 & 0.0028 & 0.000 \\
\hline FOmax & 0.0121 & 0.0076 & 0.001 & 0.0155 & 0.0093 & 0.001 & 0.0100 & 0.0105 & 0.001 & 0.0023 & 0.0028 & 0.000 \\
\hline SSDxoy & -0.0137 & 0.0186 & 0.833 & 0.0285 & 0.0499 & 0.357 & 0.2519 & 0.0908 & 0.000 & 0.5519 & 0.0899 & 0.000 \\
\hline SSDyox & 0.2367 & 0.0927 & 0.001 & 0.0973 & 0.0768 & 0.000 & -0.0027 & 0.0068 & 0.671 & 0.0022 & 0.0026 & 0.000 \\
\hline SOmax & -0.0142 & 0.0165 & 0.834 & 0.0076 & 0.0141 & 0.357 & -0.0027 & 0.0061 & 0.671 & 0.0022 & 0.0026 & 0.000 \\
\hline \multicolumn{13}{|c|}{ 31-40(x) vs. 51-65(y) } \\
\hline FSDxoy & 0.0309 & 0.0130 & 0.003 & 0.0754 & 0.0239 & 0.000 & 0.2018 & 0.0285 & 0.000 & 0.3167 & 0.0269 & 0.000 \\
\hline FSDyox & 0.0427 & 0.0203 & 0.003 & 0.0170 & 0.0076 & 0.000 & 0.0046 & 0.0036 & 0.022 & 0.0018 & 0.0021 & 0.000 \\
\hline FOmax & 0.0252 & 0.0105 & 0.006 & 0.0169 & 0.0075 & 0.000 & 0.0046 & 0.0036 & 0.022 & 0.0018 & 0.0021 & 0.000 \\
\hline SSDxoy & 0.0408 & 0.0787 & 0.439 & 0.3085 & 0.1228 & 0.000 & 0.5882 & 0.0954 & 0.000 & 1.2972 & 0.1050 & 0.000 \\
\hline SSDyox & 0.0942 & 0.0632 & 0.018 & 0.0203 & 0.0148 & 0.000 & -0.0010 & 0.0065 & 0.542 & 0.0018 & 0.0021 & 0.000 \\
\hline SOmax & 0.0089 & 0.0372 & 0.457 & 0.0197 & 0.0130 & 0.000 & -0.0010 & 0.0065 & 0.542 & 0.0018 & 0.0021 & 0.000 \\
\hline \multicolumn{13}{|c|}{$31-40(x)$ vs. age $\geq 65(y)$} \\
\hline FSDxoy & 0.0072 & 0.0044 & 0.004 & 0.0044 & 0.0031 & 0.000 & 0.0095 & 0.0051 & 0.000 & 0.0211 & 0.0117 & 0.000 \\
\hline FSDyox & 0.3727 & 0.0248 & 0.000 & 0.2866 & 0.0296 & 0.000 & 0.1517 & 0.0306 & 0.000 & 0.0533 & 0.0246 & 0.000 \\
\hline FOmax & 0.0072 & 0.0044 & 0.004 & 0.0044 & 0.0031 & 0.000 & 0.0095 & 0.0051 & 0.000 & 0.0184 & 0.0086 & 0.000 \\
\hline SSDxoy & -0.3522 & 0.0221 & 1.000 & 0.0000 & 0.0000 & 0.000 & -0.0119 & 0.0080 & 0.948 & 0.0270 & 0.0567 & 0.339 \\
\hline SSDyox & 1.1793 & 0.1021 & 0.000 & 1.3628 & 0.1615 & 0.000 & 0.3708 & 0.0830 & 0.000 & 0.1510 & 0.0965 & 0.000 \\
\hline SOmax & -0.3522 & 0.0221 & 1.000 & 0.0000 & 0.0000 & 0.000 & -0.0119 & 0.0080 & 0.948 & 0.0101 & 0.0180 & 0.339 \\
\hline \multicolumn{13}{|c|}{ 41-50(x) vs. 51-65(y) } \\
\hline FSDxoy & 0.0609 & 0.0180 & 0.000 & 0.0851 & 0.0187 & 0.000 & 0.1234 & 0.0208 & 0.000 & 0.1497 & 0.0207 & 0.000 \\
\hline FSDyox & 0.0136 & 0.0101 & 0.025 & 0.0048 & 0.0055 & 0.040 & 0.0059 & 0.0039 & 0.022 & 0.0019 & 0.0021 & 0.000 \\
\hline FOmax & 0.0135 & 0.0099 & 0.025 & 0.0048 & 0.0055 & 0.040 & 0.0059 & 0.0039 & 0.022 & 0.0019 & 0.0021 & 0.000 \\
\hline SSDxoy & 0.2485 & 0.0877 & 0.001 & 0.3749 & 0.0931 & 0.000 & 0.3899 & 0.0789 & 0.000 & 0.5506 & 0.0806 & 0.000 \\
\hline SSDyox & 0.0123 & 0.0133 & 0.156 & 0.0029 & 0.0062 & 0.376 & 0.0057 & 0.0063 & 0.175 & 0.0015 & 0.0023 & 0.000 \\
\hline SOmax & 0.0121 & 0.0127 & 0.157 & 0.0029 & 0.0062 & 0.376 & 0.0057 & 0.0063 & 0.175 & 0.0015 & 0.0023 & 0.000 \\
\hline \multicolumn{13}{|c|}{$41-50(x)$ vs. age $\geq 65(y)$} \\
\hline FSDxoy & 0.0057 & 0.0042 & 0.012 & 0.0008 & 0.0030 & 0.418 & 0.0037 & 0.0042 & 0.197 & 0.0015 & 0.0030 & 0.297 \\
\hline FSDyox & 0.3578 & 0.0234 & 0.000 & 0.2748 & 0.0246 & 0.000 & 0.2389 & 0.0239 & 0.000 & 0.1914 & 0.0218 & 0.000 \\
\hline FOmax & 0.0057 & 0.0042 & 0.012 & 0.0008 & 0.0030 & 0.418 & 0.0037 & 0.0042 & 0.197 & 0.0015 & 0.0030 & 0.297 \\
\hline SSDxoy & -0.3100 & 0.0197 & 1.000 & -0.0062 & 0.0034 & 0.973 & -0.0135 & 0.0060 & 0.995 & -0.0041 & 0.0031 & 0.902 \\
\hline SSDyox & 1.0954 & 0.0890 & 0.000 & 0.8660 & 0.0884 & 0.000 & 0.6825 & 0.0807 & 0.000 & 0.5974 & 0.0764 & 0.000 \\
\hline SOmax & -0.3100 & 0.0197 & 1.000 & -0.0062 & 0.0034 & 0.973 & -0.0135 & 0.0060 & 0.995 & -0.0041 & 0.0031 & 0.902 \\
\hline
\end{tabular}


51-65(x) vs. age $\geq 65(y)$

FSDyox

FOmax $\quad 0.0020$

SSDxoy

0.0020
-0.3362

$0.0215 \quad 0.000$

$-0.0004$

0.3346

$0.0018 \quad 0.585$

0.585
0.000

0.0031

0.3521

0.0030

0.0240

0.036

$-0.0003$

$0.0013 \quad 0.461$

$0.0032 \quad 0.251$

$-0.0004$

$0.0018 \quad 0.585$

0.0031

0.3322

$0.0218 \quad 0.000$

SSDyox

$\begin{array}{ll}0.0900 & 0.000\end{array}$

1.3654

$0.0033 \quad \mathbf{0 . 9 9 5}$

$-0.0127$

0.0068

0.036

$-0.0003$

$0.0013 \quad 0.461$

SOmax

$-0.3362$

$0.0208 \quad 1.000$

$-0.0075$

$0.0033 \quad 0.995$

$-0.0127$

0.0796

0014

$0.0015 \quad 0.633$

$0.0068 \quad 0.976$

$-0.0014$

$\begin{array}{ll}0.0884 & 0.000 \\ 0.0015 & 0.633\end{array}$
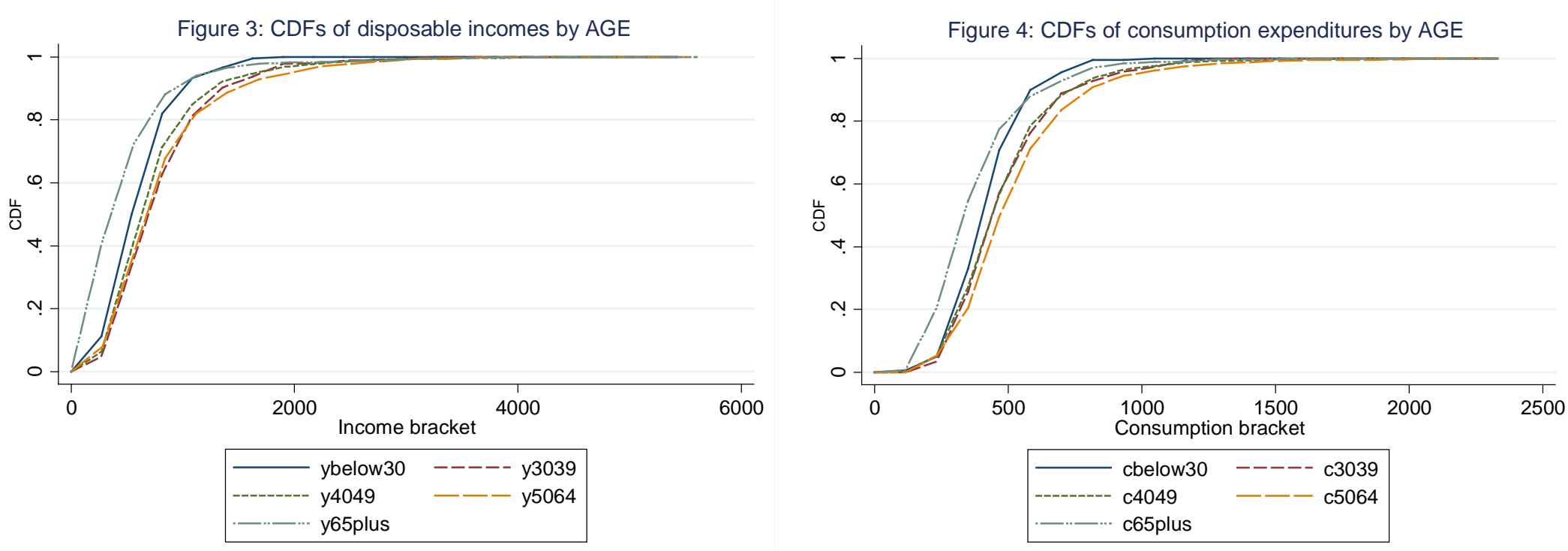
Table 5: Comparison of disposable income and consumption expenditure by EDUCATION of household head

\begin{tabular}{|c|c|c|c|c|c|c|c|c|c|c|c|c|}
\hline \multirow[b]{3}{*}{ variable } & \multicolumn{6}{|c|}{ unconditional (level) } & \multicolumn{6}{|c|}{ conditional (residual) } \\
\hline & \multicolumn{3}{|c|}{ disposable income } & \multicolumn{3}{|c|}{ consumption expenditure } & \multicolumn{3}{|c|}{ disposable income } & \multicolumn{3}{|c|}{ consumption expenditure } \\
\hline & mean & std & prob & mean & std & prob & mean & std & prob & mean & std & prob \\
\hline \multicolumn{13}{|c|}{ no schooling $(x)$ vs. 6 years $(y)$} \\
\hline FSDxoy & 0.3486 & 0.0383 & 0.000 & 0.2800 & 0.0413 & 0.000 & 0.2051 & 0.0407 & 0.000 & 0.2370 & 0.0391 & 0.000 \\
\hline FSDyox & 0.0065 & 0.0062 & 0.141 & 0.0048 & 0.0040 & 0.000 & 0.0126 & 0.0076 & 0.000 & 0.0075 & 0.0044 & 0.000 \\
\hline FOmax & 0.0065 & 0.0062 & 0.141 & 0.0048 & 0.0040 & 0.000 & 0.0126 & 0.0076 & 0.000 & 0.0075 & 0.0044 & 0.000 \\
\hline SSDxoy & 1.1096 & 0.1402 & 0.000 & 1.7338 & 0.2419 & 0.000 & 0.5235 & 0.1252 & 0.000 & 1.2227 & 0.1979 & 0.000 \\
\hline SSDyox & -0.2696 & 0.0402 & 1.000 & 0.0041 & 0.0029 & 0.000 & 0.0150 & 0.0124 & 0.000 & 0.0164 & 0.0125 & 0.000 \\
\hline SOmax & -0.2696 & 0.0402 & 1.000 & 0.0041 & 0.0029 & 0.000 & 0.0150 & 0.0124 & 0.000 & 0.0164 & 0.0125 & 0.000 \\
\hline \multicolumn{13}{|c|}{ no schooling $(x)$ vs. 9 years $(y)$} \\
\hline FSDxoy & 0.5123 & 0.0391 & 0.000 & 0.4344 & 0.0385 & 0.000 & 0.3195 & 0.0412 & 0.000 & 0.4603 & 0.0377 & 0.000 \\
\hline FSDyox & 0.0058 & 0.0058 & 0.119 & 0.0001 & 0.0005 & 0.000 & 0.0068 & 0.0053 & 0.000 & 0.0000 & 0.0006 & 0.000 \\
\hline FOmax & 0.0058 & 0.0058 & 0.119 & 0.0001 & 0.0005 & 0.000 & 0.0068 & 0.0053 & 0.000 & 0.0000 & 0.0006 & 0.000 \\
\hline SSDxoy & 1.2784 & 0.1140 & 0.000 & 2.2217 & 0.1852 & 0.000 & 0.7660 & 0.1023 & 0.000 & 2.6249 & 0.2126 & 0.000 \\
\hline SSDyox & -0.5121 & 0.0394 & 1.000 & 0.0001 & 0.0005 & 0.000 & 0.0023 & 0.0023 & 0.000 & 0.0000 & 0.0005 & 0.000 \\
\hline SOmax & -0.5121 & 0.0394 & 1.000 & 0.0001 & 0.0005 & 0.000 & 0.0023 & 0.0023 & 0.000 & 0.0000 & 0.0005 & 0.000 \\
\hline \multicolumn{13}{|c|}{ no schooling $(x)$ vs. 12 years $(y)$} \\
\hline FSDxoy & 0.5670 & 0.0368 & 0.000 & 0.4991 & 0.0381 & 0.000 & 0.4787 & 0.0360 & 0.000 & 0.5692 & 0.0372 & 0.000 \\
\hline FSDyox & 0.0023 & 0.0041 & 0.158 & 0.0000 & 0.0000 & 0.148 & 0.0058 & 0.0033 & 0.000 & 0.0013 & 0.0013 & 0.000 \\
\hline FOmax & 0.0023 & 0.0041 & 0.158 & 0.0000 & 0.0000 & 0.148 & 0.0058 & 0.0033 & 0.000 & 0.0013 & 0.0013 & 0.000 \\
\hline SSDxoy & 1.5447 & 0.0995 & 0.000 & 1.6527 & 0.0941 & 0.000 & 1.0173 & 0.0919 & 0.000 & 1.8194 & 0.0981 & 0.000 \\
\hline SSDyox & -0.5663 & 0.0376 & 1.000 & -0.0167 & 0.0097 & 0.947 & 0.0048 & 0.0022 & 0.000 & 0.0017 & 0.0018 & 0.000 \\
\hline SOmax & -0.5663 & 0.0376 & 1.000 & -0.0167 & 0.0097 & 0.947 & 0.0048 & 0.0022 & 0.000 & 0.0017 & 0.0018 & 0.000 \\
\hline \multicolumn{13}{|c|}{ no schooling $(x)$ vs. more than 12 years $(y)$} \\
\hline FSDxoy & 0.6440 & 0.0266 & 0.000 & 0.6188 & 0.0335 & 0.000 & 0.5289 & 0.0366 & 0.000 & 0.6675 & 0.0303 & 0.000 \\
\hline FSDyox & 0.0003 & 0.0035 & 0.611 & 0.0001 & 0.0004 & 0.260 & 0.0038 & 0.0049 & 0.000 & 0.0000 & 0.0000 & 0.000 \\
\hline FOmax & 0.0003 & 0.0035 & 0.611 & 0.0001 & 0.0004 & 0.260 & 0.0038 & 0.0049 & 0.000 & 0.0000 & 0.0000 & 0.000 \\
\hline SSDxoy & 2.3276 & 0.1122 & 0.000 & 2.5706 & 0.1110 & 0.000 & 1.7434 & 0.1129 & 0.000 & 2.5450 & 0.1032 & 0.000 \\
\hline SSDyox & -0.6208 & 0.0362 & 1.000 & -0.0160 & 0.0099 & 0.950 & 0.0000 & 0.0000 & 0.000 & 0.0000 & 0.0000 & 0.000 \\
\hline SOmax & -0.6208 & 0.0362 & 1.000 & -0.0160 & 0.0099 & 0.950 & 0.0000 & 0.0000 & 0.000 & 0.0000 & 0.0000 & 0.000 \\
\hline
\end{tabular}


6 years $(x)$ vs. 9 years $(y)$

\begin{tabular}{|c|c|c|c|c|c|c|c|c|c|c|c|c|}
\hline & & & & & & & & & & & & \\
\hline FSDxоу & 0.1735 & 0.0241 & 0.000 & 0.1772 & 0.0298 & 0.000 & 0.1474 & 0.0304 & 0.000 & 0.2306 & 0.0290 & 0.000 \\
\hline FSDyox & 0.0082 & 0.0053 & 0.009 & 0.0039 & 0.0043 & 0.000 & 0.0056 & 0.0050 & 0.131 & 0.0013 & 0.0034 & 0.000 \\
\hline FOmax & 0.0082 & 0.0053 & 0.009 & 0.0039 & 0.0043 & 0.000 & 0.0056 & 0.0050 & 0.131 & 0.0013 & 0.0034 & 0.000 \\
\hline SSDxоy & 0.4480 & 0.0892 & 0.000 & 0.8929 & 0.1516 & 0.000 & 0.3429 & 0.0865 & 0.000 & 1.2482 & 0.1582 & 0.000 \\
\hline SSDyox & -0.1626 & 0.0240 & 1.000 & 0.0009 & 0.0020 & 0.000 & -0.0078 & 0.0050 & 0.938 & 0.0000 & 0.0001 & 0.000 \\
\hline SOmax & -0.1626 & 0.0240 & 1.000 & 0.0009 & 0.0020 & 0.000 & -0.0078 & 0.0050 & 0.938 & 0.0000 & 0.0001 & 0.000 \\
\hline \multicolumn{13}{|c|}{6 years $(x)$ vs. 12 years $(y)$} \\
\hline FSDxoy & 0.2633 & 0.0250 & 0.000 & 0.2614 & 0.0249 & 0.000 & 0.2684 & 0.0266 & 0.000 & 0.3288 & 0.0235 & 0.000 \\
\hline FSDyox & 0.0018 & 0.0029 & 0.111 & 0.0000 & 0.0000 & 0.205 & 0.0010 & 0.0029 & 0.422 & 0.0005 & 0.0010 & 0.116 \\
\hline FOmax & 0.0018 & 0.0029 & 0.111 & 0.0000 & 0.0000 & 0.205 & 0.0010 & 0.0029 & 0.422 & 0.0005 & 0.0010 & 0.116 \\
\hline SSDxoy & 0.8237 & 0.0792 & 0.000 & 0.9299 & 0.0751 & 0.000 & 0.6433 & 0.0733 & 0.000 & 1.1123 & 0.0741 & 0.000 \\
\hline SSDyox & -0.2196 & 0.0218 & 1.000 & -0.0041 & 0.0029 & 0.862 & -0.0052 & 0.0050 & 0.864 & -0.0010 & 0.0025 & 0.591 \\
\hline SOmax & -0.2196 & 0.0218 & 1.000 & -0.0041 & 0.0029 & 0.862 & -0.0052 & 0.0050 & 0.864 & -0.0010 & 0.0025 & 0.591 \\
\hline \multicolumn{13}{|c|}{6 years $(x)$ vs. more than 12 years $(y)$} \\
\hline FSDxoy & 0.4056 & 0.0263 & 0.000 & 0.4143 & 0.0242 & 0.000 & 0.3631 & 0.0267 & 0.000 & 0.5007 & 0.0247 & 0.000 \\
\hline FSDyox & -0.0008 & 0.0017 & 0.671 & 0.0002 & 0.0006 & 0.212 & -0.0004 & 0.0019 & 0.590 & 0.0000 & 0.0000 & 0.201 \\
\hline FOmax & -0.0008 & 0.0017 & 0.671 & 0.0002 & 0.0006 & 0.212 & -0.0004 & 0.0019 & 0.590 & 0.0000 & 0.0000 & 0.201 \\
\hline SSDxoy & 1.6219 & 0.0978 & 0.000 & 1.9158 & 0.0967 & 0.000 & 1.3403 & 0.0905 & 0.000 & 1.8352 & 0.0859 & 0.000 \\
\hline SSDyox & -0.2637 & 0.0220 & 1.000 & -0.0028 & 0.0031 & 0.761 & -0.0102 & 0.0046 & 0.991 & -0.0039 & 0.0029 & 0.837 \\
\hline SOmax & -0.2637 & 0.0220 & 1.000 & -0.0028 & 0.0031 & 0.761 & -0.0102 & 0.0046 & 0.991 & -0.0039 & 0.0029 & 0.837 \\
\hline \multicolumn{13}{|c|}{9 years $(x)$ vs. 12 years $(y)$} \\
\hline FSDxoy & 0.1470 & 0.0281 & 0.000 & 0.1019 & 0.0247 & 0.000 & 0.1271 & 0.0236 & 0.000 & 0.1559 & 0.0280 & 0.000 \\
\hline FSDyox & 0.0034 & 0.0043 & 0.051 & 0.0027 & 0.0031 & 0.043 & 0.0055 & 0.0039 & 0.004 & 0.0030 & 0.0026 & 0.000 \\
\hline FOmax & 0.0034 & 0.0043 & 0.051 & 0.0027 & 0.0031 & 0.043 & 0.0055 & 0.0039 & 0.004 & 0.0030 & 0.0026 & 0.000 \\
\hline SSDxoy & 0.4007 & 0.0846 & 0.000 & 0.3881 & 0.0853 & 0.000 & 0.3504 & 0.0767 & 0.000 & 0.4774 & 0.0802 & 0.000 \\
\hline SSDyox & -0.0217 & 0.0171 & 0.900 & -0.0023 & 0.0024 & 0.621 & 0.0040 & 0.0052 & 0.171 & 0.0039 & 0.0035 & 0.000 \\
\hline SOmax & -0.0217 & 0.0171 & 0.900 & -0.0023 & 0.0024 & 0.621 & 0.0040 & 0.0052 & 0.171 & 0.0039 & 0.0035 & 0.000 \\
\hline \multicolumn{13}{|c|}{9 years $(x)$ vs. more than 12 years $(y)$} \\
\hline FSDxoy & 0.3142 & 0.0225 & 0.000 & 0.2928 & 0.0256 & 0.000 & 0.3013 & 0.0262 & 0.000 & 0.3524 & 0.0270 & 0.000 \\
\hline FSDyox & 0.0005 & 0.0024 & 0.379 & 0.0005 & 0.0009 & 0.158 & 0.0025 & 0.0034 & 0.141 & 0.0000 & 0.0000 & 0.000 \\
\hline FOmax & 0.0005 & 0.0024 & 0.379 & 0.0005 & 0.0009 & 0.158 & 0.0025 & 0.0034 & 0.141 & 0.0000 & 0.0000 & 0.000 \\
\hline SSDxоy & 1.2327 & 0.0978 & 0.000 & 1.4097 & 0.1018 & 0.000 & 1.0327 & 0.0934 & 0.000 & 1.3780 & 0.0921 & 0.000 \\
\hline SSDyox & -0.0852 & 0.0177 & 1.000 & -0.0012 & 0.0026 & 0.588 & -0.0009 & 0.0041 & 0.540 & 0.0000 & 0.0000 & 0.000 \\
\hline SOmax & -0.0852 & 0.0177 & 1.000 & -0.0012 & 0.0026 & 0.588 & -0.0009 & 0.0041 & 0.540 & 0.0000 & 0.0000 & 0.000 \\
\hline
\end{tabular}


12 years $(x)$ vs. more than 12 years $(y)$

\begin{tabular}{lrlllllllllll} 
FSDxoy & 0.2016 & 0.0220 & 0.000 & 0.1917 & 0.0202 & 0.000 & 0.1634 & 0.0200 & 0.000 & 0.1865 & 0.0224 & 0.000 \\
FSDyox & 0.0026 & 0.0027 & 0.168 & 0.0017 & 0.0011 & 0.000 & 0.0028 & 0.0032 & 0.196 & 0.0006 & 0.0009 & 0.088 \\
FOmax & 0.0026 & 0.0027 & 0.168 & 0.0017 & 0.0011 & 0.000 & 0.0028 & 0.0032 & 0.196 & 0.0006 & 0.0009 & 0.088 \\
SSDxoy & 0.8152 & 0.0881 & 0.000 & 1.0188 & 0.0944 & 0.000 & 0.6695 & 0.0819 & 0.000 & 0.8121 & 0.0766 & 0.000 \\
SSDyox & -0.0396 & 0.0109 & $\mathbf{1 . 0 0 0}$ & 0.0012 & 0.0012 & 0.000 & -0.0043 & 0.0030 & $\mathbf{0 . 9 3 7}$ & -0.0009 & 0.0010 & 0.614 \\
SOmax & -0.0396 & 0.0109 & 1.000 & 0.0012 & 0.0012 & 0.000 & -0.0043 & 0.0030 & 0.937 & -0.0009 & 0.0010 & 0.614 \\
\hline \hline
\end{tabular}


Table 6: Comparison of disposable income and consumption expenditure by HOUSEHOLD TYPE

\begin{tabular}{|c|c|c|c|c|c|c|c|c|c|c|c|c|}
\hline \multirow[b]{3}{*}{ variable } & \multicolumn{6}{|c|}{ unconditional (level) } & \multicolumn{6}{|c|}{ conditional (residual) } \\
\hline & \multicolumn{3}{|c|}{ disposable income } & \multicolumn{3}{|c|}{ consumption expenditure } & \multicolumn{3}{|c|}{ disposable income } & \multicolumn{3}{|c|}{ consumption expenditure } \\
\hline & mean & std & prob & mean & std & prob & mean & std & prob & mean & std & prob \\
\hline \multicolumn{13}{|c|}{ single $(x)$ vs. married w/o children(y) } \\
\hline FSDxoy & 0.1870 & 0.0330 & 0.000 & 0.0545 & 0.0258 & 0.004 & 0.0173 & 0.0183 & 0.066 & 0.0027 & 0.0069 & 0.357 \\
\hline FSDyox & 0.0238 & 0.0138 & 0.001 & 0.0396 & 0.0175 & 0.000 & 0.1566 & 0.0340 & 0.000 & 0.3347 & 0.0346 & 0.000 \\
\hline FOmax & 0.0238 & 0.0138 & 0.001 & 0.0319 & 0.0144 & 0.004 & 0.0173 & 0.0182 & 0.066 & 0.0027 & 0.0069 & 0.357 \\
\hline SSDxoy & 0.3947 & 0.1072 & 0.000 & 0.1514 & 0.1134 & 0.025 & -0.0314 & 0.0281 & 0.926 & -0.0476 & 0.0184 & 0.995 \\
\hline SSDyox & -0.1659 & 0.0675 & 0.957 & 0.0700 & 0.1003 & 0.000 & 0.3712 & 0.1385 & 0.000 & 1.0829 & 0.1485 & 0.000 \\
\hline SOmax & -0.1660 & 0.0672 & 0.957 & 0.0245 & 0.0325 & 0.025 & -0.0320 & 0.0250 & 0.926 & -0.0476 & 0.0184 & 0.995 \\
\hline \multicolumn{13}{|c|}{$\operatorname{single}(x)$ vs. married w/ children $(y)$} \\
\hline FSDxoy & 0.3666 & 0.0269 & 0.000 & 0.2000 & 0.0303 & 0.000 & 0.0053 & 0.0074 & 0.057 & 0.0010 & 0.0023 & 0.238 \\
\hline FSDyox & 0.0332 & 0.0154 & 0.001 & 0.0557 & 0.0185 & 0.000 & 0.1036 & 0.0295 & 0.000 & 0.2735 & 0.0296 & 0.000 \\
\hline FOmax & 0.0332 & 0.0154 & 0.001 & 0.0557 & 0.0185 & 0.000 & 0.0053 & 0.0073 & 0.057 & 0.0010 & 0.0023 & 0.238 \\
\hline SSDxoy & 0.7746 & 0.0769 & 0.000 & 0.4323 & 0.0782 & 0.000 & -0.0127 & 0.0187 & 0.769 & -0.0177 & 0.0127 & 0.919 \\
\hline SSDyox & -0.3654 & 0.0296 & 1.000 & 0.0186 & 0.0493 & 0.000 & 0.3284 & 0.1206 & 0.000 & 0.9804 & 0.1241 & 0.000 \\
\hline SOmax & -0.3654 & 0.0296 & 1.000 & 0.0183 & 0.0475 & 0.000 & -0.0127 & 0.0186 & 0.769 & -0.0177 & 0.0127 & 0.919 \\
\hline \multicolumn{13}{|c|}{ single( $x)$ vs. single w/ elderly $(y)$} \\
\hline FSDxoy & 0.1310 & 0.0375 & 0.000 & 0.0068 & 0.0138 & 0.276 & 0.0155 & 0.0170 & 0.048 & -0.0002 & 0.0056 & 0.537 \\
\hline FSDyox & 0.0668 & 0.0246 & 0.000 & 0.1120 & 0.0331 & 0.000 & 0.1758 & 0.0391 & 0.000 & 0.3434 & 0.0387 & 0.000 \\
\hline FOmax & 0.0642 & 0.0226 & 0.000 & 0.0067 & 0.0136 & 0.276 & 0.0155 & 0.0170 & 0.048 & -0.0002 & 0.0056 & 0.537 \\
\hline SSDxoy & 0.2404 & 0.0865 & 0.000 & 0.0021 & 0.0158 & 0.508 & -0.0243 & 0.0287 & 0.842 & -0.0266 & 0.0200 & 0.907 \\
\hline SSDyox & 0.0367 & 0.1460 & 0.448 & 0.6187 & 0.1872 & 0.000 & 0.4724 & 0.1483 & 0.000 & 1.2680 & 0.1494 & 0.000 \\
\hline SOmax & 0.0144 & 0.1137 & 0.448 & 0.0021 & 0.0158 & 0.508 & -0.0244 & 0.0277 & 0.842 & -0.0266 & 0.0200 & 0.907 \\
\hline \multicolumn{13}{|c|}{ single $(x)$ vs. other $(y)$} \\
\hline FSDxoy & 0.3108 & 0.0269 & 0.000 & 0.0934 & 0.0256 & 0.000 & 0.0513 & 0.0192 & 0.000 & 0.0146 & 0.0101 & 0.051 \\
\hline FSDyox & 0.0501 & 0.0174 & 0.000 & 0.0832 & 0.0179 & 0.000 & 0.0386 & 0.0159 & 0.002 & 0.1928 & 0.0246 & 0.000 \\
\hline FOmax & 0.0501 & 0.0174 & 0.000 & 0.0741 & 0.0155 & 0.000 & 0.0323 & 0.0119 & 0.002 & 0.0146 & 0.0101 & 0.051 \\
\hline SSDxоy & 0.5518 & 0.0651 & 0.000 & 0.1882 & 0.0609 & 0.000 & 0.1042 & 0.0501 & 0.003 & 0.0142 & 0.0108 & 0.081 \\
\hline SSDyox & -0.2698 & 0.0781 & 0.994 & 0.2458 & 0.1400 & 0.000 & 0.0758 & 0.0958 & 0.266 & 0.8351 & 0.1182 & 0.000 \\
\hline SOmax & -0.2698 & 0.0781 & 0.994 & 0.1376 & 0.0578 & 0.000 & 0.0334 & 0.0493 & 0.269 & 0.0142 & 0.0108 & 0.081 \\
\hline
\end{tabular}


married $w / o$ children $(x)$ vs. married $w /$ children $(y)$

\begin{tabular}{|c|c|c|c|c|c|c|c|c|c|c|c|c|}
\hline FSDxоy & 0.1877 & 0.0247 & 0.000 & 0.1688 & 0.0291 & 0.000 & 0.0416 & 0.0236 & 0.000 & 0.0916 & 0.0273 & 0.000 \\
\hline FSDyox & 0.0274 & 0.0164 & 0.003 & 0.0498 & 0.0212 & 0.000 & 0.0419 & 0.0201 & 0.007 & 0.0270 & 0.0135 & 0.001 \\
\hline FOmax & 0.0274 & 0.0164 & 0.003 & 0.0498 & 0.0211 & 0.000 & 0.0274 & 0.0143 & 0.007 & 0.0267 & 0.0130 & 0.001 \\
\hline SSDxoy & 0.4143 & 0.0773 & 0.000 & 0.4020 & 0.0737 & 0.000 & 0.0701 & 0.0537 & 0.049 & 0.2112 & 0.0739 & 0.000 \\
\hline SSDyox & -0.1709 & 0.0324 & 0.994 & 0.0007 & 0.0213 & 0.604 & 0.0546 & 0.0794 & 0.319 & -0.0214 & 0.0474 & 0.809 \\
\hline SOmax & -0.1709 & 0.0324 & 0.994 & 0.0007 & 0.0213 & 0.604 & 0.0117 & 0.0349 & 0.368 & -0.0233 & 0.0406 & 0.809 \\
\hline \multicolumn{13}{|c|}{ married w/o children( $x$ ) vs. single $w /$ elderly(y) } \\
\hline FSDxoy & 0.0123 & 0.0148 & 0.083 & 0.0028 & 0.0061 & 0.000 & 0.0385 & 0.0272 & 0.009 & 0.0529 & 0.0260 & 0.003 \\
\hline FSDyox & 0.0925 & 0.0318 & 0.000 & 0.1327 & 0.0353 & 0.000 & 0.0675 & 0.0249 & 0.001 & 0.0657 & 0.0253 & 0.000 \\
\hline FOmax & 0.0119 & 0.0138 & 0.083 & 0.0028 & 0.0060 & 0.000 & 0.0312 & 0.0191 & 0.010 & 0.0415 & 0.0185 & 0.003 \\
\hline SSDxoy & -0.0089 & 0.0376 & 0.610 & 0.0011 & 0.0043 & 0.000 & 0.0648 & 0.0800 & 0.206 & 0.1012 & 0.0674 & 0.022 \\
\hline SSDyox & 0.4475 & 0.1778 & 0.004 & 0.7641 & 0.2264 & 0.000 & 0.1657 & 0.1285 & 0.106 & 0.2382 & 0.1846 & 0.117 \\
\hline SOmax & -0.0100 & 0.0355 & 0.614 & 0.0011 & 0.0043 & 0.000 & 0.0237 & 0.0419 & 0.312 & 0.0593 & 0.0544 & 0.139 \\
\hline \multicolumn{13}{|c|}{ married w/o children $(x)$ vs. other $(y)$} \\
\hline FSDxoy & 0.1224 & 0.0239 & 0.000 & 0.0674 & 0.0253 & 0.003 & 0.1646 & 0.0294 & 0.000 & 0.1700 & 0.0283 & 0.000 \\
\hline FSDyox & 0.0550 & 0.0203 & 0.000 & 0.0857 & 0.0209 & 0.000 & 0.0384 & 0.0178 & 0.005 & 0.0395 & 0.0137 & 0.000 \\
\hline FOmax & 0.0545 & 0.0197 & 0.000 & 0.0597 & 0.0190 & 0.003 & 0.0384 & 0.0178 & 0.005 & 0.0395 & 0.0137 & 0.000 \\
\hline SSDxоy & 0.2097 & 0.0495 & 0.000 & 0.1367 & 0.0616 & 0.008 & 0.2819 & 0.0590 & 0.000 & 0.4897 & 0.0773 & 0.000 \\
\hline SSDyox & -0.0127 & 0.0993 & 0.580 & 0.2642 & 0.1444 & 0.000 & -0.0702 & 0.0222 & 0.988 & -0.0585 & 0.0187 & 0.990 \\
\hline SOmax & -0.0168 & 0.0912 & 0.580 & 0.1072 & 0.0514 & 0.008 & -0.0702 & 0.0222 & 0.988 & -0.0585 & 0.0187 & 0.990 \\
\hline \multicolumn{13}{|c|}{ married $w /$ children( $x$ ) vs. single $w /$ elderly $(y)$} \\
\hline FSDxoy & 0.0101 & 0.0079 & 0.022 & 0.0080 & 0.0075 & 0.032 & 0.0212 & 0.0198 & 0.052 & 0.0091 & 0.0097 & 0.045 \\
\hline FSDyox & 0.2271 & 0.0307 & 0.000 & 0.2800 & 0.0359 & 0.000 & 0.0620 & 0.0285 & 0.000 & 0.1145 & 0.0320 & 0.000 \\
\hline FOmax & 0.0101 & 0.0079 & 0.022 & 0.0080 & 0.0075 & 0.032 & 0.0173 & 0.0141 & 0.052 & 0.0090 & 0.0097 & 0.045 \\
\hline SSDxoy & -0.2152 & 0.0319 & 1.000 & -0.0048 & 0.0049 & 0.624 & 0.0098 & 0.0698 & 0.596 & -0.0177 & 0.0205 & 0.815 \\
\hline SSDyox & 0.6799 & 0.1249 & 0.000 & 0.8274 & 0.1345 & 0.000 & 0.1631 & 0.1017 & 0.028 & 0.3284 & 0.1101 & 0.001 \\
\hline SOmax & -0.2152 & 0.0319 & 1.000 & -0.0048 & 0.0049 & 0.624 & -0.0080 & 0.0348 & 0.624 & -0.0178 & 0.0203 & 0.816 \\
\hline \multicolumn{13}{|c|}{ married $w /$ children $(x)$ vs. other $(y)$} \\
\hline FSDxoy & 0.0043 & 0.0040 & 0.029 & 0.0033 & 0.0019 & 0.009 & 0.1283 & 0.0219 & 0.000 & 0.0870 & 0.0180 & 0.000 \\
\hline FSDyox & 0.0945 & 0.0204 & 0.000 & 0.1072 & 0.0188 & 0.000 & 0.0083 & 0.0067 & 0.034 & 0.0198 & 0.0101 & 0.001 \\
\hline FOmax & 0.0043 & 0.0040 & 0.029 & 0.0033 & 0.0019 & 0.009 & 0.0083 & 0.0067 & 0.034 & 0.0198 & 0.0101 & 0.001 \\
\hline SSDxoy & -0.0547 & 0.0104 & 1.000 & -0.0040 & 0.0018 & 0.992 & 0.2701 & 0.0552 & 0.000 & 0.1953 & 0.0476 & 0.000 \\
\hline SSDyox & 0.3034 & 0.0726 & 0.000 & 0.4046 & 0.0736 & 0.000 & -0.0542 & 0.0119 & 0.999 & -0.0284 & 0.0109 & 0.987 \\
\hline SOmax & -0.0547 & 0.0104 & 1.000 & -0.0040 & 0.0018 & 0.992 & -0.0542 & 0.0119 & 0.999 & -0.0284 & 0.0109 & 0.987 \\
\hline
\end{tabular}


single $w /$ elderly $(x)$ vs. other(y)

\begin{tabular}{lrlllllllllll} 
FSDxoy & 0.1638 & 0.0303 & 0.000 & 0.1692 & 0.0331 & 0.000 & 0.1702 & 0.0356 & 0.000 & 0.1776 & 0.0299 & 0.000 \\
FSDyox & 0.0126 & 0.0091 & 0.016 & 0.0176 & 0.0124 & 0.000 & 0.0096 & 0.0077 & 0.092 & 0.0133 & 0.0102 & 0.056 \\
FOmax & 0.0126 & 0.0091 & 0.016 & 0.0176 & 0.0124 & 0.000 & 0.0096 & 0.0077 & 0.092 & 0.0133 & 0.0102 & 0.056 \\
SSDxoy & 0.3928 & 0.1041 & 0.000 & 0.5196 & 0.1170 & 0.000 & 0.3942 & 0.0949 & 0.000 & 0.5475 & 0.1040 & 0.000 \\
SSDyox & -0.1502 & 0.0528 & $\mathbf{0 . 9 7 0}$ & 0.0041 & 0.0019 & 0.000 & -0.0755 & 0.0261 & $\mathbf{0 . 9 8 9}$ & -0.0190 & 0.0133 & $\mathbf{0 . 9 2 7}$ \\
SOmax & -0.1502 & 0.0528 & 0.970 & 0.0041 & 0.0019 & 0.000 & -0.0755 & 0.0261 & 0.989 & -0.0190 & 0.0133 & 0.927 \\
\hline \hline
\end{tabular}


Table 7: Comparison of disposable income and consumption expenditure by MARITAL STATUS of household head

\begin{tabular}{|c|c|c|c|c|c|c|c|c|c|c|c|c|}
\hline \multirow[b]{3}{*}{ variable } & \multicolumn{6}{|c|}{ unconditional (level) } & \multicolumn{6}{|c|}{ conditional (residual) } \\
\hline & \multicolumn{3}{|c|}{ disposable income } & \multicolumn{3}{|c|}{ consumption expenditure } & \multicolumn{3}{|c|}{ disposable income } & \multicolumn{3}{|c|}{ consumption expenditure } \\
\hline & mean & std & prob & mean & std & prob & mean & std & prob & mean & std & prob \\
\hline \multicolumn{13}{|c|}{ never married(x) vs. married(y) } \\
\hline FSDxoy & 0.0501 & 0.0214 & 0.000 & 0.0728 & 0.0241 & 0.000 & 0.1301 & 0.0236 & 0.000 & 0.1636 & 0.0263 & 0.000 \\
\hline FSDyox & 0.0291 & 0.0166 & 0.032 & 0.0284 & 0.0133 & 0.003 & 0.0008 & 0.0034 & 0.718 & 0.0013 & 0.0031 & 0.431 \\
\hline FOmax & 0.0245 & 0.0133 & 0.032 & 0.0276 & 0.0126 & 0.003 & 0.0008 & 0.0034 & 0.718 & 0.0013 & 0.0031 & 0.431 \\
\hline SSDxoy & 0.1160 & 0.0674 & 0.005 & 0.1799 & 0.0739 & 0.001 & 0.4435 & 0.0775 & 0.000 & 0.5358 & 0.0793 & 0.000 \\
\hline SSDyox & 0.0024 & 0.0565 & 0.636 & 0.0145 & 0.0363 & 0.432 & -0.0610 & 0.0146 & 1.000 & -0.0124 & 0.0059 & 0.995 \\
\hline SOmax & -0.0089 & 0.0366 & 0.641 & 0.0107 & 0.0256 & 0.433 & -0.0610 & 0.0146 & 1.000 & -0.0124 & 0.0059 & 0.995 \\
\hline \multicolumn{13}{|c|}{ never married(x) vs. seperated/divorced/widowed(y) } \\
\hline FSDxoy & 0.0077 & 0.0045 & 0.012 & 0.0007 & 0.0015 & 0.152 & 0.0143 & 0.0054 & 0.000 & 0.0063 & 0.0059 & 0.069 \\
\hline FSDyox & 0.3343 & 0.0289 & 0.000 & 0.1732 & 0.0270 & 0.000 & 0.2284 & 0.0292 & 0.000 & 0.2177 & 0.0316 & 0.000 \\
\hline FOmax & 0.0077 & 0.0045 & 0.012 & 0.0007 & 0.0015 & 0.152 & 0.0143 & 0.0054 & 0.000 & 0.0063 & 0.0059 & 0.069 \\
\hline SSDxoy & -0.2056 & 0.0201 & 1.000 & -0.0052 & 0.0030 & 0.948 & -0.0603 & 0.0176 & 1.000 & 0.0018 & 0.0083 & 0.420 \\
\hline SSDyox & 1.4779 & 0.1611 & 0.000 & 0.8886 & 0.1480 & 0.000 & 0.7162 & 0.1029 & 0.000 & 0.7223 & 0.1260 & 0.000 \\
\hline SOmax & -0.2056 & 0.0201 & 1.000 & -0.0052 & 0.0030 & 0.948 & -0.0603 & 0.0176 & 1.000 & 0.0018 & 0.0083 & 0.420 \\
\hline \multicolumn{13}{|c|}{ married(x) vs. seperated/divorced/widowed(y) } \\
\hline FSDxoy & 0.0041 & 0.0044 & 0.201 & 0.0001 & 0.0015 & 0.665 & 0.0037 & 0.0040 & 0.090 & 0.0002 & 0.0007 & 0.286 \\
\hline FSDyox & 0.3270 & 0.0207 & 0.000 & 0.2357 & 0.0228 & 0.000 & 0.3817 & 0.0222 & 0.000 & 0.3041 & 0.0218 & 0.000 \\
\hline FOmax & 0.0041 & 0.0044 & 0.201 & 0.0001 & 0.0015 & 0.665 & 0.0037 & 0.0040 & 0.090 & 0.0002 & 0.0007 & 0.286 \\
\hline SSDxoy & -0.3045 & 0.0209 & 1.000 & -0.0037 & 0.0033 & 0.877 & -0.1459 & 0.0161 & 1.000 & -0.0179 & 0.0059 & 1.000 \\
\hline SSDyox & 1.0031 & 0.0786 & 0.000 & 0.8374 & 0.0821 & 0.000 & 0.8950 & 0.0680 & 0.000 & 0.9883 & 0.0683 & 0.000 \\
\hline SOmax & -0.3045 & 0.0209 & 1.000 & -0.0037 & 0.0033 & 0.877 & -0.1459 & 0.0161 & 1.000 & -0.0179 & 0.0059 & 1.000 \\
\hline
\end{tabular}


Table 8: Comparison of disposable income and consumption expenditure by SEX of household head

\begin{tabular}{|c|c|c|c|c|c|c|c|c|c|c|c|c|}
\hline \multirow[b]{3}{*}{ variable } & \multicolumn{6}{|c|}{ unconditional (level) } & \multicolumn{6}{|c|}{ conditional (residual) } \\
\hline & \multicolumn{3}{|c|}{ disposable income } & \multicolumn{3}{|c|}{ consumption expenditure } & \multicolumn{3}{|c|}{ disposable income } & \multicolumn{3}{|c|}{ consumption expenditure } \\
\hline & mean & std & prob & mean & std & prob & mean & std & prob & mean & std & prob \\
\hline \multicolumn{13}{|c|}{ female $(x)$ vs. male $(y)$} \\
\hline FSDxoy & 0.2306 & 0.0172 & 0.000 & 0.1774 & 0.0201 & 0.000 & 0.0606 & 0.0177 & 0.000 & 0.0650 & 0.0195 & 0.000 \\
\hline FSDyox & 0.0053 & 0.0050 & 0.126 & 0.0034 & 0.0032 & 0.095 & 0.0065 & 0.0069 & 0.103 & 0.0048 & 0.0048 & 0.079 \\
\hline FOmax & 0.0053 & 0.0050 & 0.126 & 0.0034 & 0.0032 & 0.095 & 0.0064 & 0.0066 & 0.103 & 0.0047 & 0.0047 & 0.079 \\
\hline SSDxoy & 0.6002 & 0.0720 & 0.000 & 0.5659 & 0.0752 & 0.000 & 0.1613 & 0.0567 & 0.000 & 0.1779 & 0.0579 & 0.000 \\
\hline SSDyox & -0.2270 & 0.0178 & 1.000 & -0.0056 & 0.0029 & 0.985 & -0.0186 & 0.0117 & 0.972 & -0.0016 & 0.0054 & 0.714 \\
\hline SOmax & -0.2270 & 0.0178 & 1.000 & -0.0056 & 0.0029 & 0.985 & -0.0188 & 0.0107 & 0.972 & -0.0018 & 0.0038 & 0.714 \\
\hline
\end{tabular}


Table 9: Comparison of disposable income and consumption expenditure by OCCUPATION of household head

\begin{tabular}{|c|c|c|c|c|c|c|c|c|c|c|c|c|}
\hline \multirow[b]{3}{*}{ variable } & \multicolumn{6}{|c|}{ unconditional (level) } & \multicolumn{6}{|c|}{ conditional (residual) } \\
\hline & \multicolumn{3}{|c|}{ disposable income } & \multicolumn{3}{|c|}{ consumption expenditure } & \multicolumn{3}{|c|}{ disposable income } & \multicolumn{3}{|c|}{ consumption expenditure } \\
\hline & mean & std & prob & mean & std & prob & mean & std & prob & mean & std & prob \\
\hline \multicolumn{13}{|c|}{ professionals $(x)$ vs. service sector(y) } \\
\hline FSDxoy & 0.0024 & 0.0027 & 0.119 & 0.0003 & 0.0008 & 0.182 & 0.0072 & 0.0080 & 0.101 & 0.0027 & 0.0038 & 0.121 \\
\hline FSDyox & 0.2334 & 0.0214 & 0.000 & 0.2646 & 0.0228 & 0.000 & 0.1487 & 0.0231 & 0.000 & 0.1806 & 0.0210 & 0.000 \\
\hline FOmax & 0.0024 & 0.0027 & 0.119 & 0.0003 & 0.0008 & 0.182 & 0.0072 & 0.0080 & 0.101 & 0.0027 & 0.0038 & 0.121 \\
\hline SSDxoy & -0.1121 & 0.0130 & 1.000 & -0.0009 & 0.0009 & 0.634 & -0.0006 & 0.0148 & 0.520 & -0.0003 & 0.0071 & 0.541 \\
\hline SSDyox & 0.9213 & 0.0967 & 0.000 & 1.2124 & 0.1016 & 0.000 & 0.5241 & 0.0981 & 0.000 & 0.6654 & 0.0837 & 0.000 \\
\hline SOmax & -0.1121 & 0.0130 & 1.000 & -0.0009 & 0.0009 & 0.634 & -0.0006 & 0.0148 & 0.520 & -0.0003 & 0.0071 & 0.541 \\
\hline \multicolumn{13}{|c|}{ professionals $(x)$ vs. agriculture\&handicrafts $(y)$} \\
\hline FSDxoy & 0.0029 & 0.0020 & 0.053 & 0.0000 & 0.0000 & 0.304 & 0.0177 & 0.0137 & 0.009 & 0.0034 & 0.0047 & 0.262 \\
\hline FSDyox & 0.3070 & 0.0226 & 0.000 & 0.3536 & 0.0252 & 0.000 & 0.1777 & 0.0221 & 0.000 & 0.2088 & 0.0250 & 0.000 \\
\hline FOmax & 0.0029 & 0.0020 & 0.053 & 0.0000 & 0.0000 & 0.304 & 0.0177 & 0.0137 & 0.009 & 0.0034 & 0.0047 & 0.262 \\
\hline SSDxoy & -0.1343 & 0.0157 & 1.000 & -0.0055 & 0.0028 & 0.977 & 0.0154 & 0.0168 & 0.190 & 0.0027 & 0.0059 & 0.348 \\
\hline SSDyox & 1.2498 & 0.0995 & 0.000 & 1.5948 & 0.1036 & 0.000 & 0.5855 & 0.0928 & 0.000 & 0.8241 & 0.0915 & 0.000 \\
\hline SOmax & -0.1343 & 0.0157 & 1.000 & -0.0055 & 0.0028 & 0.977 & 0.0154 & 0.0168 & 0.190 & 0.0027 & 0.0059 & 0.348 \\
\hline \multicolumn{13}{|c|}{ service sector(x) vs. agriculture\&handicrafts(y) } \\
\hline FSDxoy & 0.0015 & 0.0019 & 0.050 & 0.0001 & 0.0007 & 0.211 & 0.0221 & 0.0137 & 0.001 & 0.0098 & 0.0086 & 0.019 \\
\hline FSDyox & 0.0826 & 0.0212 & 0.000 & 0.0915 & 0.0188 & 0.000 & 0.0411 & 0.0146 & 0.000 & 0.0393 & 0.0138 & 0.000 \\
\hline FOmax & 0.0015 & 0.0019 & 0.050 & 0.0001 & 0.0007 & 0.211 & 0.0197 & 0.0113 & 0.001 & 0.0092 & 0.0074 & 0.019 \\
\hline SSDxoy & -0.0322 & 0.0177 & 0.968 & -0.0041 & 0.0024 & 0.936 & 0.0266 & 0.0218 & 0.091 & 0.0123 & 0.0163 & 0.163 \\
\hline SSDyox & 0.3545 & 0.0767 & 0.000 & 0.4623 & 0.0892 & 0.000 & 0.1203 & 0.0663 & 0.037 & 0.1544 & 0.0693 & 0.010 \\
\hline SOmax & -0.0322 & 0.0177 & 0.968 & -0.0041 & 0.0024 & 0.936 & 0.0205 & 0.0184 & 0.128 & 0.0101 & 0.0119 & 0.173 \\
\hline
\end{tabular}


Table 10: Comparison of disposable income and consumption expenditure by PROVINCE of residence

\begin{tabular}{|c|c|c|c|c|c|c|c|c|c|c|c|c|}
\hline \multirow[b]{3}{*}{ variable } & \multicolumn{6}{|c|}{ unconditional (level) } & \multicolumn{6}{|c|}{ conditional (residual) } \\
\hline & \multicolumn{3}{|c|}{ disposable income } & \multicolumn{3}{|c|}{ consumption expenditure } & \multicolumn{3}{|c|}{ disposable income } & \multicolumn{3}{|c|}{ consumption expenditure } \\
\hline & mean & std & prob & mean & std & prob & mean & std & prob & mean & std & prob \\
\hline \multicolumn{13}{|c|}{ capital(x) vs. highly urbanized(y) } \\
\hline FSDxoy & 0.0055 & 0.0051 & 0.025 & 0.0028 & 0.0039 & 0.033 & 0.0155 & 0.0103 & 0.000 & 0.0097 & 0.0088 & 0.011 \\
\hline FSDyox & 0.0731 & 0.0196 & 0.000 & 0.0622 & 0.0175 & 0.000 & 0.0711 & 0.0217 & 0.000 & 0.0470 & 0.0207 & 0.000 \\
\hline FOmax & 0.0055 & 0.0051 & 0.025 & 0.0028 & 0.0039 & 0.033 & 0.0153 & 0.0099 & 0.000 & 0.0089 & 0.0075 & 0.011 \\
\hline SSDxoy & -0.0437 & 0.0145 & 0.998 & -0.0018 & 0.0019 & 0.932 & 0.0173 & 0.0192 & 0.150 & 0.0111 & 0.0158 & 0.250 \\
\hline SSDyox & 0.2748 & 0.0855 & 0.000 & 0.2993 & 0.0919 & 0.000 & 0.1417 & 0.0714 & 0.018 & 0.1387 & 0.0733 & 0.017 \\
\hline SOmax & -0.0437 & 0.0145 & 0.998 & -0.0018 & 0.0019 & 0.932 & 0.0145 & 0.0158 & 0.168 & 0.0087 & 0.0124 & 0.267 \\
\hline \multicolumn{13}{|c|}{ capital(x) vs. less urbanized(y) } \\
\hline FSDxoy & -0.0011 & 0.0020 & 0.627 & 0.0008 & 0.0012 & 0.153 & 0.0023 & 0.0043 & 0.111 & 0.0004 & 0.0032 & 0.451 \\
\hline FSDyox & 0.1586 & 0.0234 & 0.000 & 0.1751 & 0.0216 & 0.000 & 0.1116 & 0.0221 & 0.000 & 0.1342 & 0.0256 & 0.000 \\
\hline FOmax & -0.0011 & 0.0020 & 0.627 & 0.0008 & 0.0012 & 0.153 & 0.0023 & 0.0043 & 0.111 & 0.0004 & 0.0032 & 0.451 \\
\hline SSDxoy & -0.1282 & 0.0183 & 1.000 & -0.0046 & 0.0023 & 0.978 & -0.0159 & 0.0151 & 0.859 & -0.0023 & 0.0053 & 0.723 \\
\hline SSDyox & 0.6595 & 0.0992 & 0.000 & 0.8649 & 0.0987 & 0.000 & 0.3343 & 0.0846 & 0.000 & 0.4626 & 0.0832 & 0.000 \\
\hline SOmax & -0.1282 & 0.0183 & 1.000 & -0.0046 & 0.0023 & 0.978 & -0.0159 & 0.0151 & 0.859 & -0.0023 & 0.0053 & 0.723 \\
\hline \multicolumn{13}{|c|}{ highly urbanized(x) vs. less urbanized(y) } \\
\hline FSDxoy & 0.0002 & 0.0018 & 0.510 & 0.0011 & 0.0012 & 0.098 & 0.0018 & 0.0026 & 0.111 & 0.0016 & 0.0019 & 0.139 \\
\hline FSDyox & 0.0969 & 0.0183 & 0.000 & 0.1260 & 0.0175 & 0.000 & 0.0521 & 0.0177 & 0.000 & 0.0938 & 0.0198 & 0.000 \\
\hline FOmax & 0.0002 & 0.0018 & 0.510 & 0.0011 & 0.0012 & 0.098 & 0.0018 & 0.0026 & 0.111 & 0.0016 & 0.0019 & 0.139 \\
\hline SSDxoy & -0.0848 & 0.0163 & 1.000 & -0.0026 & 0.0026 & 0.844 & -0.0220 & 0.0121 & 0.959 & -0.0006 & 0.0038 & 0.556 \\
\hline SSDyox & 0.3681 & 0.0744 & 0.000 & 0.5945 & 0.0773 & 0.000 & 0.1975 & 0.0621 & 0.000 & 0.3547 & 0.0648 & 0.000 \\
\hline SOmax & -0.0848 & 0.0163 & 1.000 & -0.0026 & 0.0026 & 0.844 & -0.0220 & 0.0121 & 0.959 & -0.0006 & 0.0038 & 0.556 \\
\hline
\end{tabular}


Table 11: Comparison of disposable income and consumption expenditure by HEALTH of household head

\begin{tabular}{|c|c|c|c|c|c|c|c|c|c|c|c|c|}
\hline \multirow[b]{3}{*}{ variable } & \multicolumn{6}{|c|}{ unconditional (level) } & \multicolumn{6}{|c|}{ conditional (residual) } \\
\hline & \multicolumn{3}{|c|}{ disposable income } & \multicolumn{3}{|c|}{ consumption expenditure } & \multicolumn{3}{|c|}{ disposable income } & \multicolumn{3}{|c|}{ consumption expenditure } \\
\hline & mean & std & prob & mean & std & prob & mean & std & prob & mean & std & prob \\
\hline \multicolumn{13}{|c|}{ poor/very poor(x) vs. fair(y) } \\
\hline FSDxoy & 0.3035 & 0.0247 & 0.000 & 0.2663 & 0.0256 & 0.000 & 0.1096 & 0.0249 & 0.000 & 0.1239 & 0.0254 & 0.000 \\
\hline FSDyox & 0.0013 & 0.0019 & 0.179 & -0.0002 & 0.0016 & 0.482 & 0.0014 & 0.0021 & 0.069 & 0.0018 & 0.0035 & 0.075 \\
\hline FOmax & 0.0013 & 0.0019 & 0.179 & -0.0002 & 0.0016 & 0.482 & 0.0014 & 0.0021 & 0.069 & 0.0018 & 0.0035 & 0.075 \\
\hline SSDxoy & 0.9544 & 0.0931 & 0.000 & 1.0742 & 0.1095 & 0.000 & 0.3937 & 0.0791 & 0.000 & 0.4936 & 0.0909 & 0.000 \\
\hline SSDyox & -0.2354 & 0.0222 & 1.000 & -0.0022 & 0.0028 & 0.755 & -0.0236 & 0.0094 & 0.993 & -0.0108 & 0.0046 & 0.994 \\
\hline SOmax & -0.2354 & 0.0222 & 1.000 & -0.0022 & 0.0028 & 0.755 & -0.0236 & 0.0094 & 0.993 & -0.0108 & 0.0046 & 0.994 \\
\hline \multicolumn{13}{|c|}{ poor/very poor(x) vs. excellent/good(y) } \\
\hline FSDxоy & 0.3883 & 0.0190 & 0.000 & 0.3630 & 0.0223 & 0.000 & 0.2050 & 0.0206 & 0.000 & 0.1952 & 0.0231 & 0.000 \\
\hline FSDyox & -0.0008 & 0.0015 & 0.815 & 0.0000 & 0.0014 & 0.577 & 0.0007 & 0.0020 & 0.450 & 0.0001 & 0.0015 & 0.576 \\
\hline FOmax & -0.0008 & 0.0015 & 0.815 & 0.0000 & 0.0014 & 0.577 & 0.0007 & 0.0020 & 0.450 & 0.0001 & 0.0015 & 0.576 \\
\hline SSDxоy & 1.3536 & 0.0751 & 0.000 & 1.2757 & 0.0801 & 0.000 & 0.6881 & 0.0672 & 0.000 & 0.6797 & 0.0698 & 0.000 \\
\hline SSDyox & -0.3708 & 0.0209 & 1.000 & -0.0063 & 0.0035 & 0.970 & -0.0322 & 0.0102 & 1.000 & -0.0171 & 0.0060 & 0.999 \\
\hline SOmax & -0.3708 & 0.0209 & 1.000 & -0.0063 & 0.0035 & 0.970 & -0.0322 & 0.0102 & 1.000 & -0.0171 & 0.0060 & 0.999 \\
\hline \multicolumn{13}{|c|}{ fair(x) vs. excellent/good(y) } \\
\hline FSDxoy & 0.1444 & 0.0207 & 0.000 & 0.1084 & 0.0181 & 0.000 & 0.1334 & 0.0213 & 0.000 & 0.1094 & 0.0202 & 0.000 \\
\hline FSDyox & 0.0009 & 0.0025 & 0.465 & 0.0009 & 0.0028 & 0.416 & 0.0011 & 0.0027 & 0.438 & 0.0040 & 0.0033 & 0.057 \\
\hline FOmax & 0.0009 & 0.0025 & 0.465 & 0.0009 & 0.0028 & 0.416 & 0.0011 & 0.0027 & 0.438 & 0.0040 & 0.0033 & 0.057 \\
\hline SSDxoy & 0.5518 & 0.0786 & 0.000 & 0.4508 & 0.0799 & 0.000 & 0.3870 & 0.0707 & 0.000 & 0.3411 & 0.0672 & 0.000 \\
\hline SSDyox & -0.0808 & 0.0133 & 1.000 & -0.0019 & 0.0019 & 0.772 & -0.0078 & 0.0069 & 0.877 & 0.0038 & 0.0045 & 0.176 \\
\hline SOmax & -0.0808 & 0.0133 & 1.000 & -0.0019 & 0.0019 & 0.772 & -0.0078 & 0.0069 & 0.877 & 0.0038 & 0.0045 & 0.176 \\
\hline
\end{tabular}

